\title{
From Ligand to Phosphor: Rapid, Machine-Assisted Syntheses of Substituted Iridium(III)-Pyrazolate Complexes with Tuneable Luminescence
}

Lara M. Groves, ${ }^{\text {[a] }}$ Christiane Schotten, ${ }^{[[a]}$ Joseph Beames, ${ }^{[a]}$ James A. Platts, ${ }^{[a]}$ Simon J. Coles, ${ }^{[b]}$ Peter N. Horton, ${ }^{[b]}$ Duncan L. Browne ${ }^{\star[a]}$ and Simon J.A. Pope ${ }^{\star[a]}$

${ }^{a}$ L.M. Groves, C. Schotten, Dr. J. Beames, Dr. J. A. Platts, Dr. D.L. Browne, Dr. S.J.A. Pope

School of Chemistry, Main Building, Park Place, Cardiff University, Cardiff, U.K CF10 3AT

b Prof. S.J. Coles, Dr. P.N. Horton

UK National Crystallographic Service, Chemistry, University of Southampton, Highfield, Southampton, UK SO17 1BJ.

E-mail: PopeSJ@cardiff.ac.uk, DLBrowne@cardiff.ac.uk

Keywords: Multistep continuous flow; Ligand synthesis; Iridium Complexes; Phosphorescent Materials;

Abstract

A first generation machine-assisted approach towards the preparation of hybrid ligand/metal materials has been explored. A comparison of synthetic approaches demonstrates that incorporation of both flow chemistry and microwave heating, can be successfully applied to the rapid synthesis of a range of new phenyl-1H-pyrazoles $(\mathrm{ppz})$ substituted with electron withdrawing groups $\left(-\mathrm{F},-\mathrm{CF}_{3},-\mathrm{OCF}_{3},-\mathrm{SF}_{5}\right)$, and these, in turn, can be translated in to heteroleptic complexes, $\left[\operatorname{Ir}(\mathrm{ppz})_{2}(\mathrm{bipy}) \mathrm{BF}_{4}\right.$ (bipy = 2,2'-bipyridine). Microwave-assisted syntheses for the Irll' complexes allows isolation of spectroscopically pure species in less than 1 hour of reaction time from $\mathrm{IrCl}_{3}$. All new complexes have been explored photophysically (including nanosecond time-resolved transient absorption spectroscopy), electrochemically and by TD-DFT studies which show that the complexes possess ligand-dependent, and thus, tuneable green-yellow luminescence $(500-560 \mathrm{~nm})$, with quantum yields in the range $5-15 \%$.

\section{Introduction}

In recent years, a surge in the use of machine-assisted practice in the synthesis laboratory has begun to streamline the discovery and scale-up of organic molecules with biological activity, such as pharmaceuticals, agrochemicals, flavours and fragrances. ${ }^{[1]}$ The use of robotic microwaves with touchscreen user interfaces and continuous flow apparatus has led to systems that can operate un-manned in a 24/7 regime and deliver results and data to human operators. The recent addition of computer control, inline analytics ${ }^{[2]}$ and optimising algorithms ${ }^{[3]}$ has already afforded early examples of machines capable of the unassisted optimisation of chemical reactions. Further, the addition of automated biological assays into the machineassisted discovery loop has now led to a closed-loop machine platform that is 
capable of optimising compound potency through iterative synthesis, characterisation and screening cycles. ${ }^{[4]}$ Clearly these methods have the potential to be extremely powerful and greatly assist in the pursuit of new or improved material properties. However, to date there have been few applications of these techniques to the area of inorganic synthesis including the preparation of metal complexes. ${ }^{[5]}$ Of interest to us is the development of such a machine-assisted approach for the preparation of ligand/metal hybrid materials that exhibit tuneable properties (Figure 1). Such a technology platform could then be used to design and search for materials that have application in a broad range of disciplines ${ }^{[6]}$ including: OLEDs, ${ }^{[7]}$ photosensitisers in catalysis (including photoredox), ${ }^{[8]}$ cellular bioimaging, ${ }^{[9]}$ piezochromics ${ }^{[10]}$ and as responsive materials for data recording. ${ }^{[11]}$ Often, the finetuning of the physicochemical properties of such complexes lies in the design and screening of the organic ligand component. Several strategies are available for tuning ${ }^{[12]}$ the luminescent properties of cationic cyclometalated metal complexes, ${ }^{[13]}$ but advances in the efficient, rapid and cost-effective synthesis of such species are rarely employed and yet highly desirable. Thus, our work herein is represented in Figure $1(A)$, and considered as the underpinning work for a future machine-assisted approach for the synthesis and optimisation of materials properties (B). In addition to the current state-of the art process for materials optimization we envisage machineassistance would consist of real-time characterization of material properties and input of this data into a computer. The computer would offer multiple purposes such as, reaction or property optimization through statistical analysis, data storage, and, management and direction of the synthetic steps.

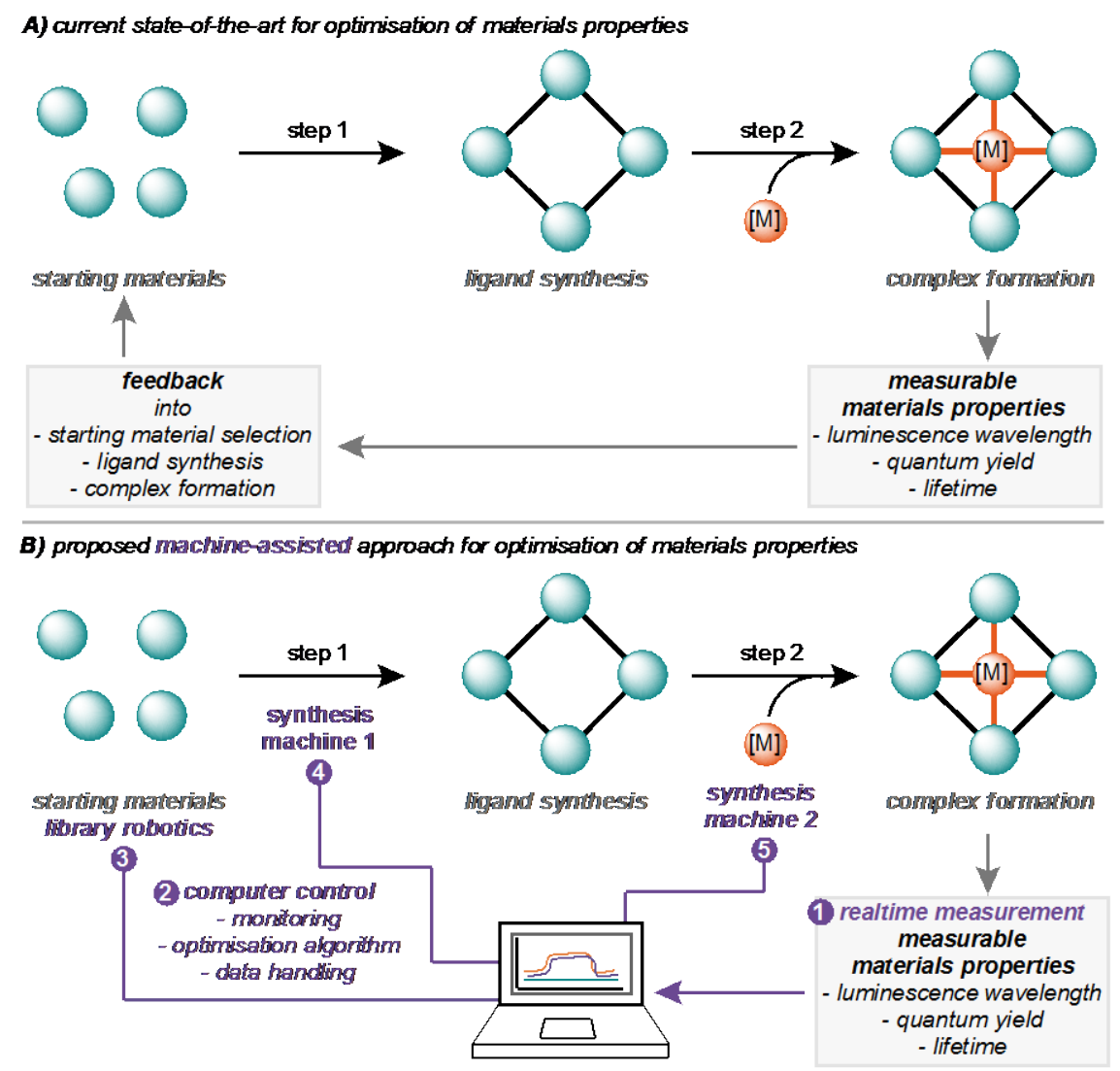

Figure 1. This work: proof of concept, chemistry model validation and development of synthesis machines 1 and 2 . 
For the computer to be able to interface with the synthetic reaction steps of the process the reactions should be carried out by a technique that can readily interface with computer control. Our first-generation approach towards this goal consists of the demonstration of a modular flow/microwave hybrid approach to the synthesis of a novel series of ligands, demonstration of a microwave approach to the assembly of the complexes and identification of suitable model chemical system with which to explore this concept. With regards to the chemistry model, cyclometalated iridium(III) complexes have been demonstrated to have a broad range of applications, and specifically offer the opportunity as tuneable wavelength phosphors. Ir ${ }^{\text {III }}$ complexes are particularly interesting around photoredox catalysis. Encouraged by recent work which has characterised a modular metal-free process for the preparation of pyrazole heterocycles via a vitamin $\mathrm{C}$ medicated reduction of diazonium salts, we opted to explore a novel series of iridium-pyrazolate materials. ${ }^{[14]}$

\section{Results and Discussion}

Phenyl-pyrazoles were targeted as ligands with electron withdrawing, fluorinecontaining phenyl substituents that would firstly permit facile $\mathrm{C}-\mathrm{H}$ insertion/cyclometalation following initial coordination of the pyrazole nitrogen to an iridium centre. Secondly, the ligand should induce a strong element of electronic tuning to the iridium colour centre. A family of such fluorinated pyrazole-iridium complexes have not been reported. Enhancing the electron withdrawing capability of the coordinating phenyl unit is known to blue shift the emission wavelength of luminescent Ir III complexes. ${ }^{[13]}$ Our approach is outlined in Scheme 1 and features the input of the appropriately fluorinated aniline(s) into the continuous flow apparatus for the ligand synthesis phase. This was followed by a two-step iridium ligation process in which both batch and microwave approaches were compared.

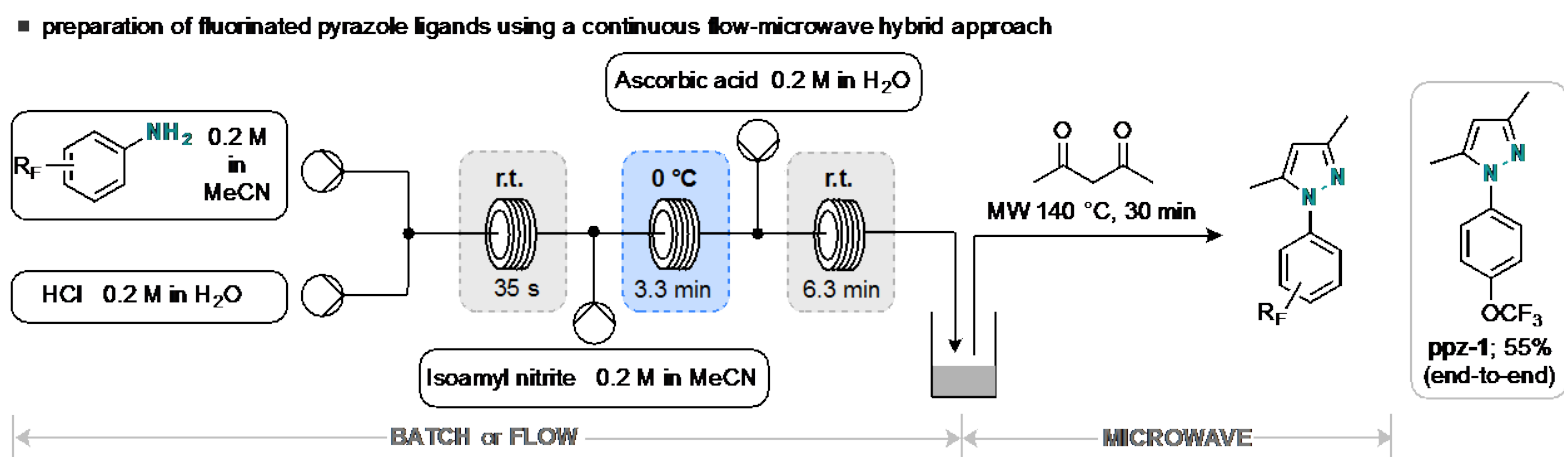

Scheme 1. Preparation of fluorinated pyrazole ligands using a continuous flow-microwave hybrid approach.

The substituted pyrazoles (ppz-1 to ppz-6) were synthesised from a selected aniline (4-(trifluoromethoxy)aniline, 3-(trifluoromethyl)aniline, 4-(trifluoromethyl)aniline, 4(pentafluorothio)aniline, 3-(pentafluorothio)aniline, 4-fluoroaniline), which was firstly diazotised in the flow reactor (Scheme 2) by combination with a stream of $\mathrm{HCl}$ and isoamylnitrite, before combination with a further stream that delivered the ascorbic acid for reduction to the oxamayl-hydrazide derivative. The formed hydrazine 
surrogate was then collected in a microwave vial before combining with acetylacetone and irradiation at $140^{\circ} \mathrm{C}$ for 30 minutes.
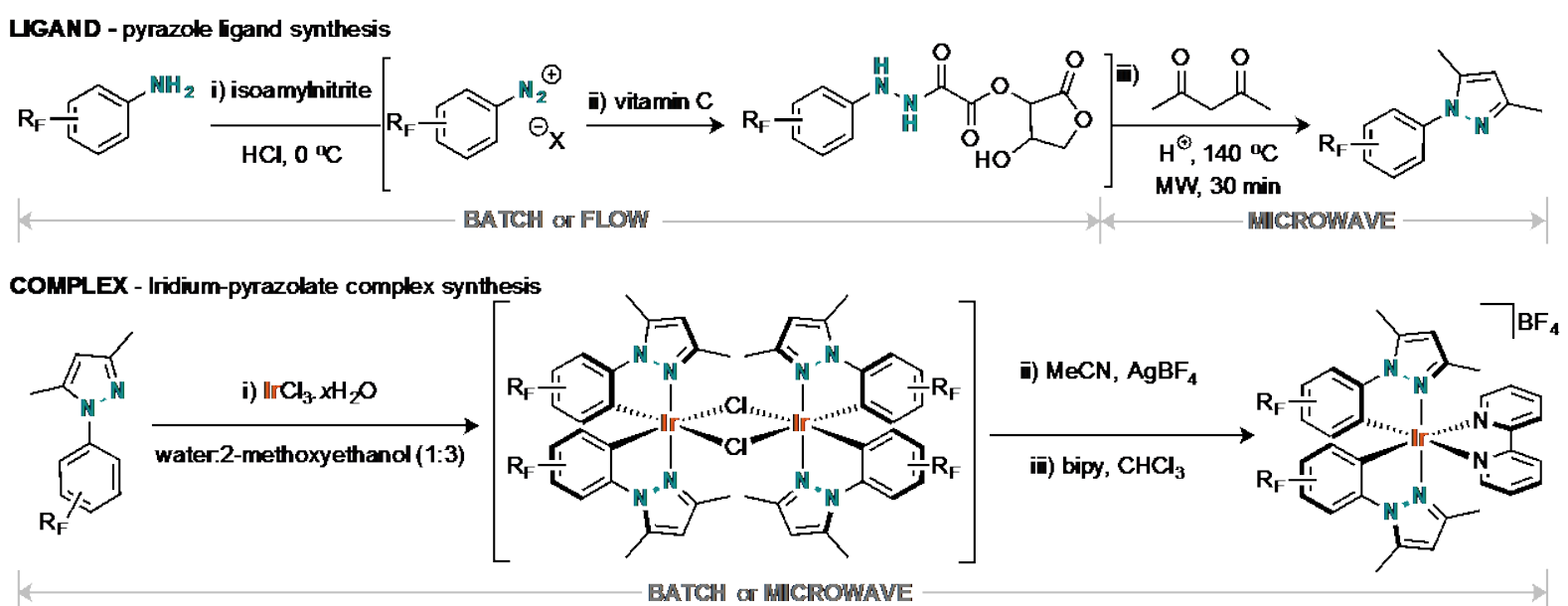

Scheme 2. Summary of the synthetic routes to the ligands and complexes.

The resultant product was purified by aqueous extraction and silica chromatography to furnish the fluorous substituted 3,5-dimethyl pyrazoles (ppz-X) in good-to-excellent yield. The utilised 'flow+microwave' setup is shown schematically in Scheme 2. It should be noted that whilst the present study concerns the design and development of automatable machines, this chemistry can also be conducted more conventionally (batch) in a round-bottom-flask (CAUTION: for the latter approach, where unknown diazonium entities are being generated, we would advise small scale reactions given the potential for diazoniums to undergo uncontrollable energy release). Thus, the flow process for the generation and consumption of diazonium salts affords safety benefits as well as versatility and the potential for automation. 


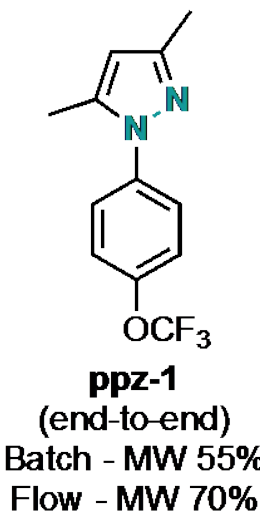<smiles>Cc1cc(C)n(-c2ccc(S(F)(F)F)cc2)n1</smiles>

ppz-4

(end-to-end)

Batch - MW 73\%

Flow - MW 72\%

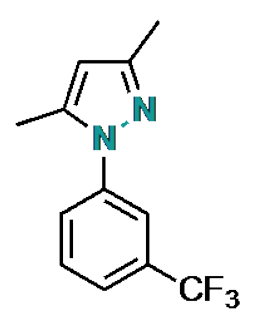

ppz-2 (end-to-end)

Batch - MW 40\%

Flow - MW 48\%<smiles>Cc1cc(C)n(-c2ccc(F)cc2)n1</smiles>

ppz-5

(end-to-end)

Batch - MW 57\%

Flow - MW 57\%<smiles>Cc1cc(C)n(-c2ccc(C(F)(F)F)cc2)n1</smiles>

ppz-3 (end-to-end)

Batch - MW 74\%

Flow - MW 84\%<smiles>Cc1cc(C)n(-c2cccc(S(F)(F)(F)(F)F)c2)n1</smiles>

ppz-6

(end-to-end)

Batch - MW 73\%

Flow - MW 62\%

Scheme 3. Structures and comparison of preparative yields of the substituted phenylpyrazole ligands.

These fluorinated pyrazoles (Scheme 3) were then successfully utilised as cyclometalating ligands with $\mid{ }^{\prime \prime I}$, thus delivering six new complexes of the general form $\left[\operatorname{Ir}(\mathrm{ppz})_{2}(\mathrm{bipy})\right] \mathrm{BF}_{4}$. Firstly, the complexes were synthesised by applying wellknown batch chemistry conditions ${ }^{[15]}$ for the dimeric precursors $\left[(p p z){ }_{2} \operatorname{Ir}(\mu-\right.$ $\left.\mathrm{Cl})_{2} \operatorname{Ir}(\mathrm{ppz})_{2}\right]$ (reaction duration $\left.48 \mathrm{hrs}\right)$. Each $\left[(\mathrm{ppz})_{2} \operatorname{Ir}(\mu-\mathrm{Cl})_{2} \operatorname{Ir}(\mathrm{ppz})_{2}\right]$ compound was then reacted with $\mathrm{AgBF}_{4}$ in $\mathrm{MeCN}_{\text {(2 }} \mathrm{hrs}$ ) to give the corresponding bis-acetonitrile adduct $\left[\operatorname{Ir}(\mathrm{ppz})_{2}(\mathrm{MeCN})_{2}\right] \mathrm{BF}_{4}$ (Scheme 2), and subsequent reaction with 2,2'bipyridine gave facile conversion ( $24 \mathrm{hrs}$ ) to the mixed-ligand target complexes $\left[\operatorname{Ir}(\mathrm{ppz})_{2}(\mathrm{bipy})\right] \mathrm{BF}_{4}$. The six complexes were isolated as powders of a pale greenbrown colouration.

At this point we assessed the usefulness of a machine approach for the iridium chemistry. ${ }^{[16]}$ During the course of our own studies, Stephenson and co-workers reported a significant reduction in the reaction times for complex formation using a microwave method for the two-step synthesis of cyclometalated Ir ${ }^{\text {III }}$ complexes in ethylene glycol. ${ }^{[17]}$ Davies and co-workers have described microwave reaction conditions using ${ }^{\mathrm{PrOH}}$ as solvent, which successfully gave cyclometalated Ir ${ }^{\text {III }}$ dimer species. ${ }^{[18]}$ Here the microwave approach was applied to each of the three steps: (i) $\left[(\mathrm{ppz})_{2} \operatorname{Ir}(\mu-\mathrm{Cl})_{2} \operatorname{Ir}(\mathrm{ppz})_{2}\right]$ from $\mathrm{IrCl}_{3}$ in 2-methoxyethanol for $15 \mathrm{~min}$ at $180{ }^{\circ} \mathrm{C}$; (ii) dimer cleavage to cis-[Ir(ppz) $2\left(\mathrm{MeCN}_{2}\right] \mathrm{BF}_{4}$ achieved in acetonitrile for $10 \mathrm{~min}$ at $120{ }^{\circ} \mathrm{C}$; (iii) conversion to $\left[\operatorname{Ir}(\mathrm{ppz})_{2}\right.$ (bipy)]BF $\mathrm{BF}_{4}$ in chloroform for $15 \mathrm{~min}$ at $130^{\circ} \mathrm{C}$. Using this microwave-assisted approach, the target $\left[\operatorname{Ir}(\mathrm{ppz})_{2}(\mathrm{bipy})\right] \mathrm{BF}_{4}$ complexes were much more rapidly isolated with total reaction times of $<1 \mathrm{hr}$. The yields of the target 
complexes are respectable and directly comparable to conventional methods, where $74 \mathrm{hrs}$ are required to isolate these species. However, the complexes (Scheme 4) are now obtainable within a day, including work-up procedures and purification via column chromatography (if required).

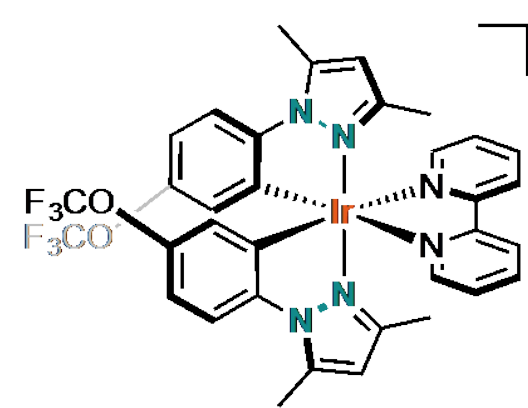

[Ir(ppz-1)2

$74 \mathrm{~h}$, Batch $60 \%$

$1 \mathrm{~h}, \mathrm{MW} 40 \%$

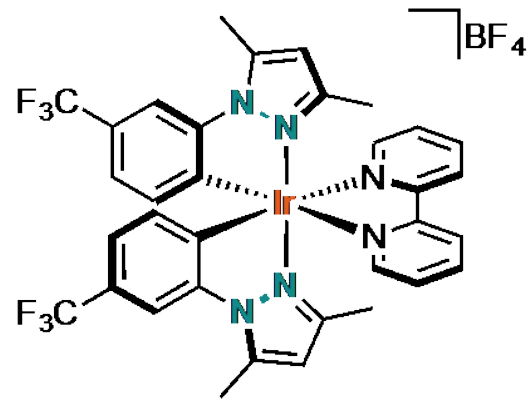

[Ir(ppz-2)2 2 (bipy)]BF 4

$74 \mathrm{~h}$, Batch $84 \%$

$1 \mathrm{~h}, \mathrm{MW} 57 \%$

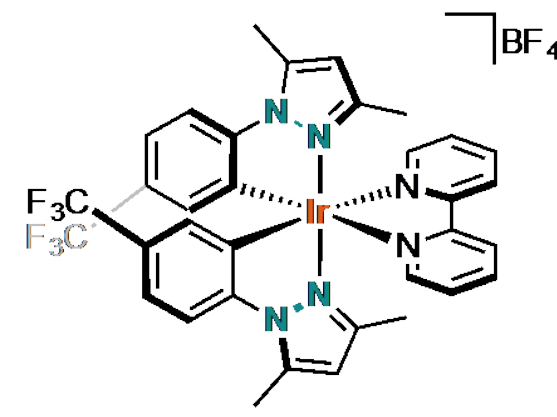

[Ir(ppz-3) 2 (bipy)]BF 4

$74 \mathrm{~h}$, Batch $71 \%$

$1 \mathrm{~h}$, MW 22\%

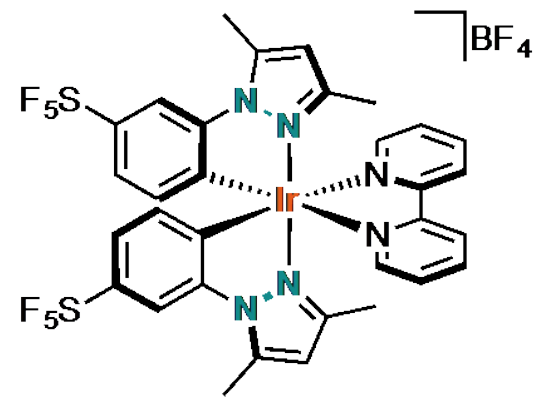

[Ir(ppz-4)2(bipy)]BF 4

$74 \mathrm{~h}$, Batch $52 \%$

$1 \mathrm{~h}, \mathrm{MW} 76 \%$

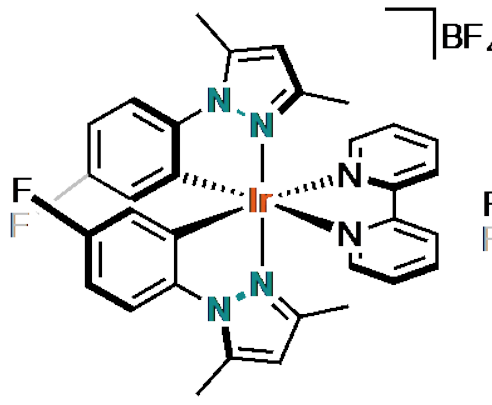

[Ir(ppz-5)2 2 (bipy)]BF 4

$74 \mathrm{~h}$, Batch $56 \%$

$1 \mathrm{~h}, \mathrm{MW} 53 \%$

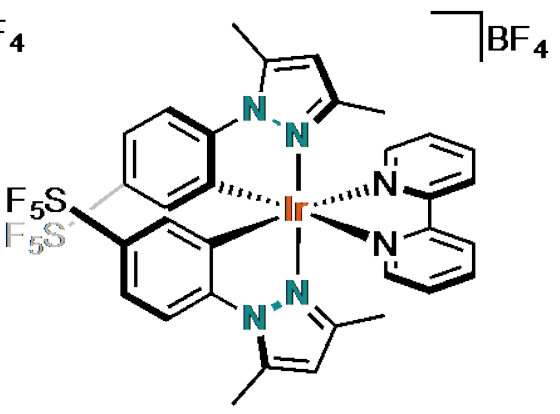

[Ir(ppz-6) $)_{2}\left({\text { bipy })] B F_{4}}_{4}\right.$

$74 \mathrm{~h}$, Batch $78 \%$

$1 \mathrm{~h}, \mathrm{MW} 71 \%$

Scheme 4. Structures, total reaction times and comparative yields (final step) of the isolated Ir'II-pyrazolato complexes.

\section{Characterisation of the complexes}


Pleasingly from the perspective of inline analytics, the complexes were reasonably soluble in a range of common organic solvents allowing rapid characterization in the solution state using ${ }^{1} \mathrm{H},{ }^{13} \mathrm{C}\left\{{ }^{1} \mathrm{H}\right\}$, IR, high resolution mass spectrometry, UV-vis., time-resolved transient absorption and luminescence spectroscopies, as well as cyclic voltammetry. Supporting TD-DFT calculations were also used to assist and inform the assignments of the electronic transitions noted from experimental observations. Confirmation of the solid-state structures were provided through X-ray crystallographic studies on two examples.

\section{X-ray crystallographic structural studies}

Crystals suitable for X-ray diffraction were obtained by vapour diffusion of diethyl ether into concentrated MeCN solutions of the respective complex. In this manner, two examples were obtained describing the solid-state structures of [Ir(ppz$\left.{ }_{3}\right)_{2}($ bipy) $] \mathrm{BF}_{4}$ and $\left[\mathrm{Ir}(\mathrm{ppz}-6)_{2}(\right.$ bipy) $] \mathrm{BF}_{4}$ (Figure 2). Data collection parameters are shown in Table S1 (ESI), together with supporting bond length (Table S2) and bond angle data (Table S3). These structures revealed the anticipated formulations for both complexes and demonstrate retention of the different pyrazolato substituents. In both cases the cyclometalating units are arranged with the coordinated $\mathrm{C}$ atoms in $\mathrm{a}$ cis arrangement. The bond angles show a distorted octahedral geometry at Ir"II in both cases. 

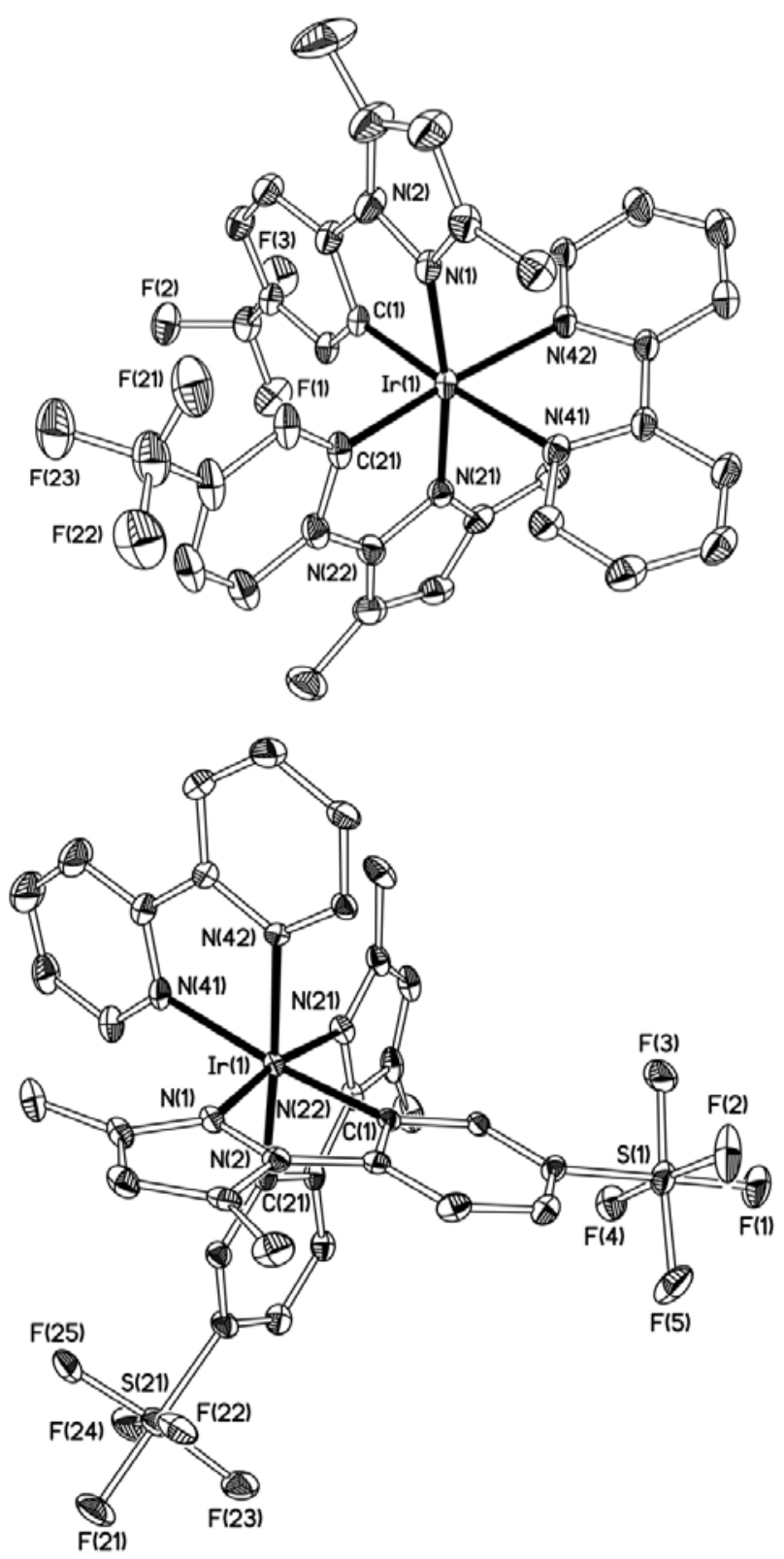

Figure 2. Molecular structures of the iridium complexes (top: $\left[\operatorname{Ir}(\mathrm{ppz}-3)_{2}(\mathrm{bipy})\right] \mathrm{BF}_{4}$; bottom: $\left[\operatorname{Ir}(\mathrm{ppz}-6)_{2}\left(\mathrm{bipy}_{\mathrm{p}}\right] \mathrm{BF}_{4}\right)$. Thermal ellipsoids drawn at the $30 \%$ probability level. Hydrogen atoms, anions and solvent molecules are omitted for clarity.

\section{Density functional theory (DFT) studies}

Frontier molecular orbital data for the six Ir ${ }^{\text {III }}$ complexes, calculated after full geometry optimisation, are reported in Table 1 . They show a consistent HOMOLUMO gap of around $3 \mathrm{eV}$ with minor changes due to the nature and position of the fluorinated substituents on the cyclometalated ligand fragments. This is in broad agreement with the electrochemical data discussed later in Table 3, but with a slight overestimation. In all cases, the HOMO has mixed iridium $5 d$ (12.5 to $21.9 \%)$ and pyrazolate $\pi$-character, with the $-\mathrm{SF}_{5}$ substituents increasing the Ir contribution, while the LUMO is wholly located on the ancillary bipyridine ligand, as shown in Figure 3. 
To probe the spectroscopy of these complexes in more detail, TD-DFT calculations were carried out on $\left[\operatorname{Ir}(\mathrm{ppz}-5)_{2}(\mathrm{bipy})\right]^{+}$, using the CAM-B3LYP functional. Strong singlet transitions were predicted to lie in the range of 270 to $300 \mathrm{~nm}$, the most intense of which at $272 \mathrm{~nm}$ is dominated by a $\pi-\pi^{\star}$ transition within the bipyridine ligand. Lower energy triplet absorption bands are also predicted at 422 and $388 \mathrm{~nm}$ : at the scalar relativistic level used for these calculations, such bands are formally forbidden with an intensity of exactly zero. The orbital make-up of the $422 \mathrm{~nm}$ band is complex, with MOs as low as HOMO-16 (metal $5 d$ / bipy $\pi$ ) contributing, but it is interesting to note that the predicted dominant contribution is HOMO-6 $\rightarrow$ LUMO, which is also a $\pi-\pi^{\star}$ transition within bipyridine. This data therefore suggests that the shoulder seen in absorption spectra could comprise a ${ }^{3} \mathrm{~L}$ bipy transition, which is presumably weakly allowed due to spin-orbit coupling that stems from smaller contributions from a ${ }^{3} \mathrm{MLCT}$ transition. TD-DFT was also used to examine emission from the geometry optimised lowest triplet excited state of $\left[\operatorname{Ir}(\mathrm{ppz}-5)_{2}(\mathrm{bipy})\right]^{+}$. Once again, such bands are formally forbidden so no information on intensity is available, but this approach predicts emission at $510 \mathrm{~nm}$, again in qualitative agreement with the experimental data. However, as with the triplet absorption, this band is dominated by intra-ligand transitions within the bipyridine with smaller ${ }^{3} \mathrm{MLCT}$ type contributions also noted, the latter a much more likely assignment to the broad featureless emission observed in the experiments.
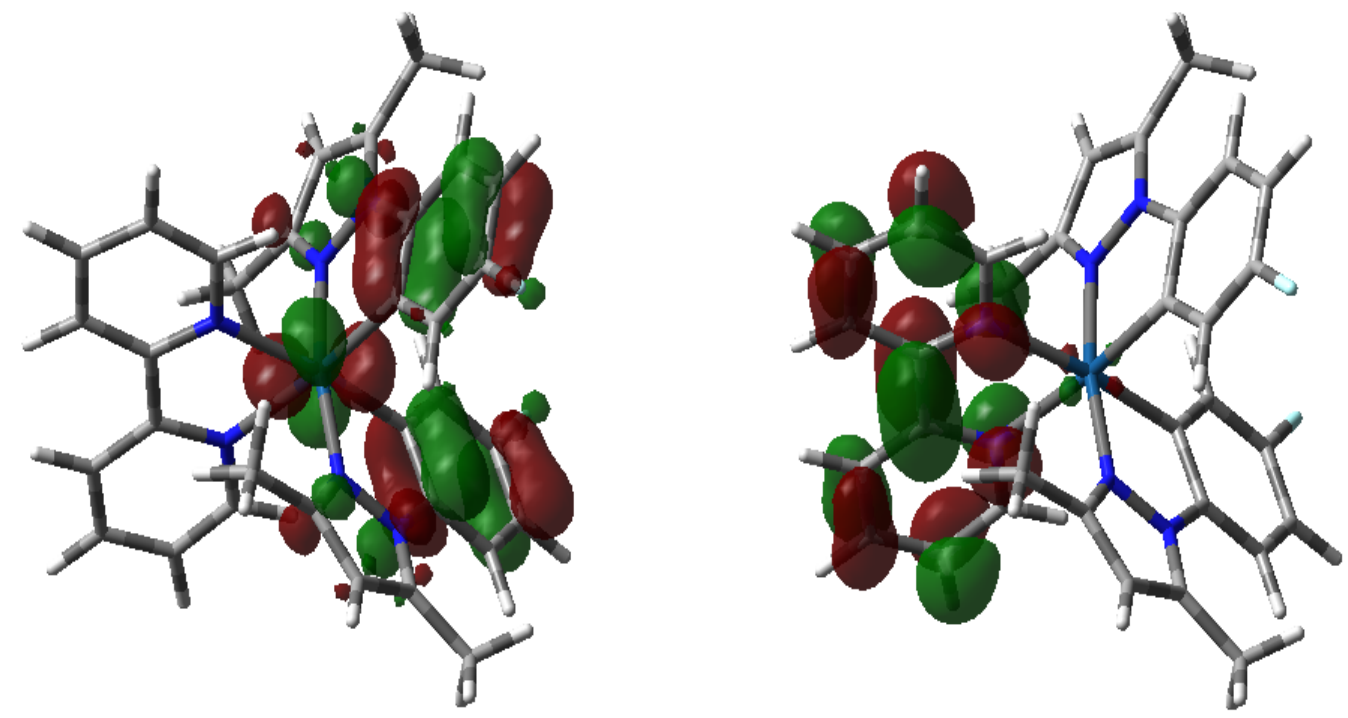

Figure 3. Isosurface plots for HOMO (left) and LUMO (right) of $\left[\operatorname{Ir}(p p z-5)_{2}(\text { bipy })\right]^{+}$, displayed at 0.04 au.

\section{Electronic and redox properties of the complexes}


The UV-vis. absorption spectra of the complexes (Figure 4) were obtained on aerated acetonitrile solutions and show several common features between 250 and $450 \mathrm{~nm}$. Ligand-centred $\left({ }^{1} \pi-\pi^{\star}\right)$ transitions dominate, with high molar absorption coefficients, $<320 \mathrm{~nm}$. A much weaker feature, present as a shoulder between 400 and $450 \mathrm{~nm}$ is tentatively assigned as a ${ }^{1} \mathrm{MLCT}$ transition with the possibility of a spin forbidden ${ }^{3} \mathrm{MLCT}$ also contributing. The position of the MLCT band(s) appear to be relatively insensitive to the variations in substituent (nature and position) that are present on the cyclometalated pyrazole ligand. Luminescence spectra were obtained (Figure 5 and Table 2) on aerated acetonitrile solutions. Using an excitation wavelength of $380 \mathrm{~nm}$ the complexes revealed a broad featureless emission peak that ranged between 510 and $560 \mathrm{~nm}$ (Figure 5) depending upon the nature of the pyrazole ligand. For comparison, [Ir(ppy)2(bipy)]PF 6 (ppy = 2-phenylpyridine) emits at $602 \mathrm{~nm}$ from a mixed ${ }^{3} \mathrm{MLCT} /{ }^{3}$ LLCT excited state; ${ }^{[19]}$ the more closely related [Ir(ppz)2(bipy)]PF6 (ppz = 2-phenylpyrazole) emits at $563 \mathrm{~nm}$ in MeCN. ${ }^{[20]}$ In this study, the most red-shifted emission was induced by para-fluorination of the cyclometalating ligand in $\left[\operatorname{Ir}(\mathrm{ppz}-5)_{2}\left(\mathrm{bipy}_{\mathrm{p}}\right) \mathrm{BF}_{4}\right.$, whilst the blue-shifted variants were the pentafluorosulfanyl derivatives $\left[\operatorname{Ir}(\mathrm{ppz}-4)_{2}(\mathrm{bipy})\right] \mathrm{BF}_{4}$ and $\left[\operatorname{Ir}(\mathrm{ppz}-6)_{2}(\mathrm{bipy})\right] \mathrm{BF}_{4}$ (meta substitution induced the highest energy emission). These $\lambda_{\mathrm{em}}$ trends are supported by the $E_{\text {bandgap }}$ data from the TD-DFT calculations (Table 1). The data suggests that in these complexes the electron withdrawing capacity of -SF 5 is greater than $-\mathrm{CF}_{3},-\mathrm{OCF}_{3}$ and $-\mathrm{F}$. It is noteworthy that pentafluorosulfanyl-substituted $\left[\operatorname{Ir}(\text { ppy })_{2} \text { (bipy) }\right]^{+}$species have recently been shown to possess blue-shifted emission properties. ${ }^{[21]}$ Low temperature (77K) spectra revealed a general hypsochromic shift in the emission maxima together with stronger vibrational features in the peak appearance (Figure 5 inset). The aerated, solution state quantum yields (5-19\%) were also obtained together with the luminescence lifetimes (Table 2), which lie in the range 77-123 ns. From these values, $k_{r}$ and $k_{n r}$ were determined for the different complexes (Table 2) and the resultant data shows a clear correlation between the energy of the emission maximum and $k_{n r}$ (and thus in accordance with the energy gap law). Therefore, for these complexes the nature of the emitting state, which we attribute to a strong ${ }^{3} \mathrm{MLCT}$ character, is likely to be closely comparable across the series. 


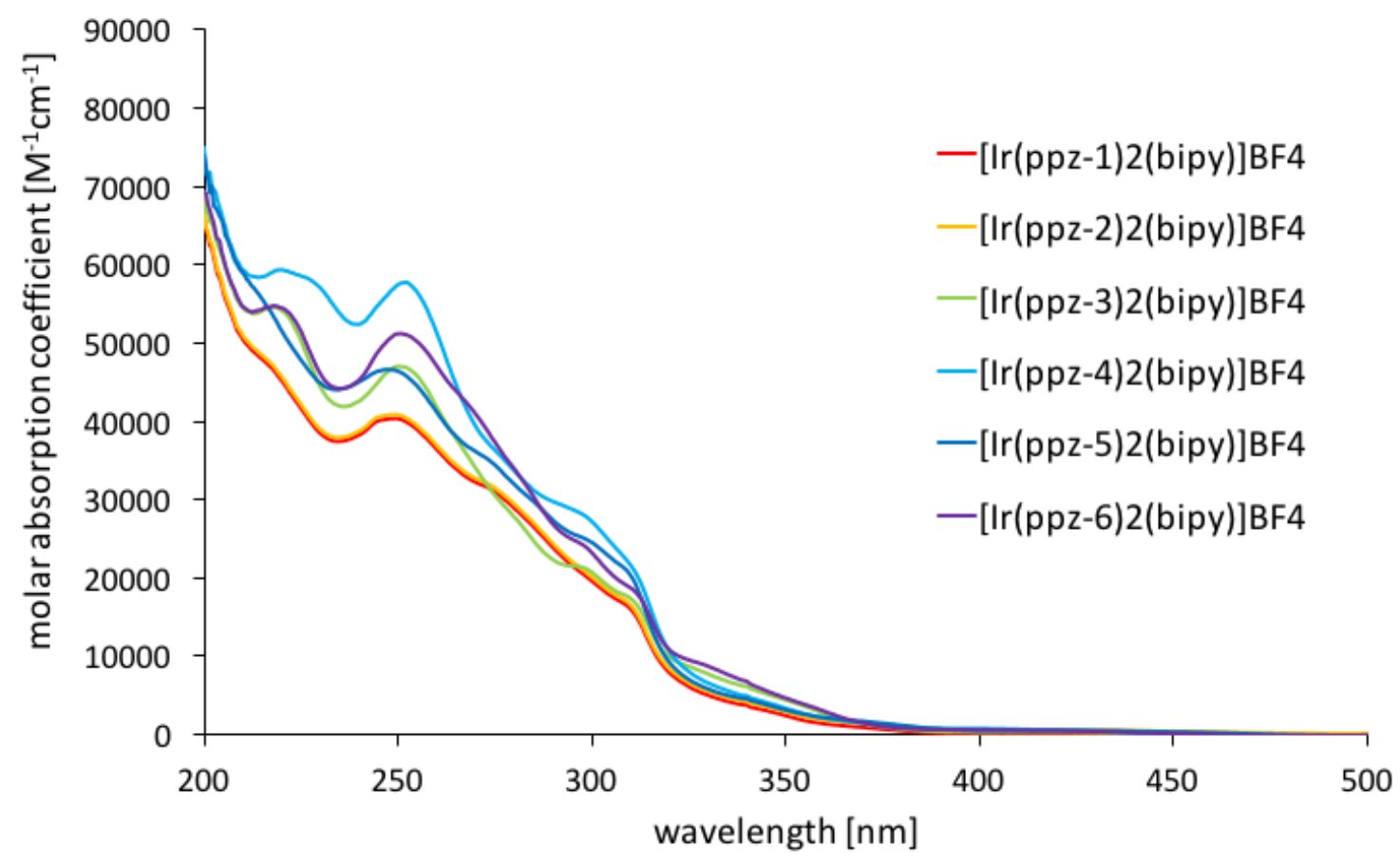

Figure 4. Comparison of the UV-vis. spectra for the complexes (in MeCN).

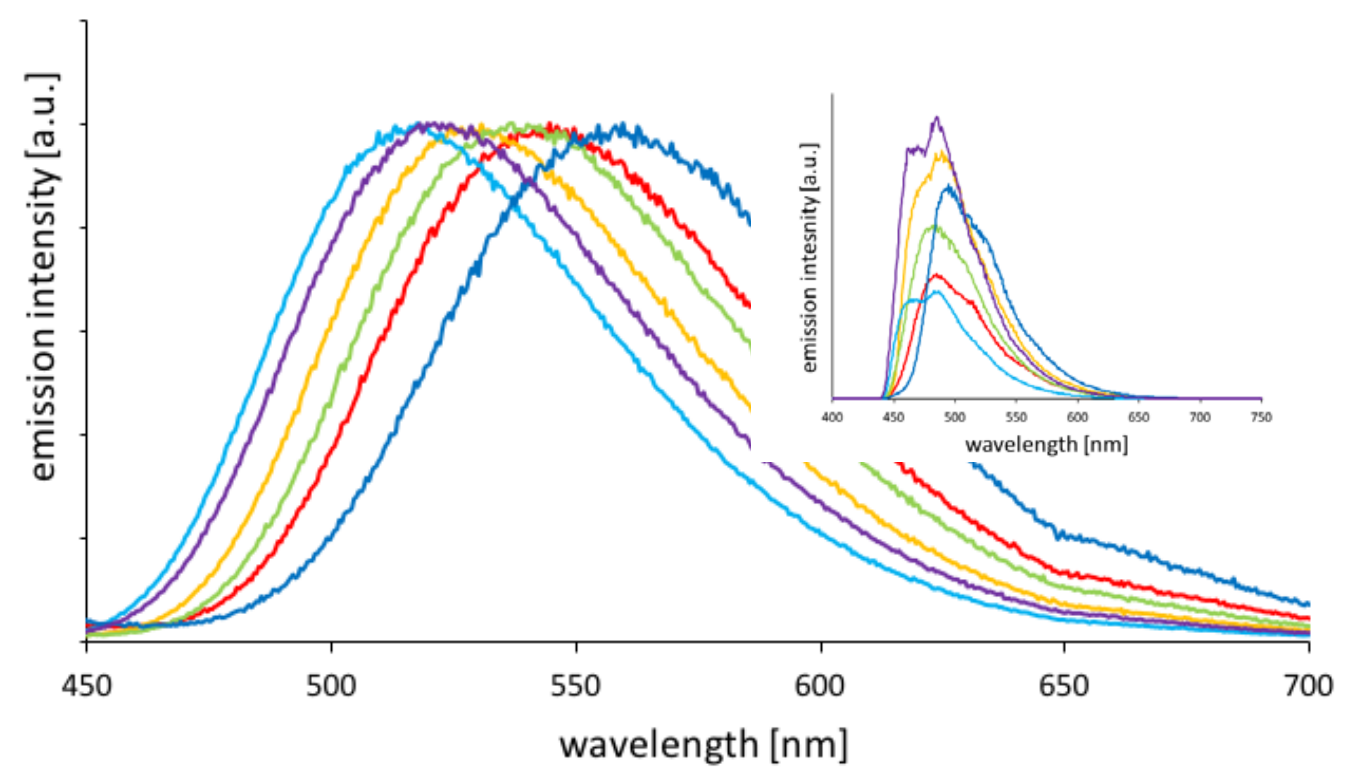

- $[\operatorname{Ir}(\mathrm{ppz}-1) 2$ (bipy) $] \mathrm{BF} 4$

- $[\operatorname{Ir}(\mathrm{ppz}-3) 2(\mathrm{bipy})] \mathrm{BF} 4$

- $[\operatorname{Ir}(\mathrm{ppz}-5) 2($ bipy) $] \mathrm{BF} 4$

- $[\operatorname{Ir}(\mathrm{ppz}-2) 2($ bipy) $] \mathrm{BF} 4$

- $[\operatorname{lr}(\mathrm{ppz}-4) 2(\mathrm{bipy})] \mathrm{BF} 4$

- $[\operatorname{Ir}(\mathrm{ppz}-6) 2$ (bipy)]BF4

Figure 5. Main: Normalised emission spectra of the complexes ( $\mathrm{MeCN}, \lambda_{\mathrm{ex}}=380 \mathrm{~nm}$ ). Foreground: emission spectra at $77 \mathrm{~K}\left(\mathrm{MeOH} / \mathrm{EtOH}\right.$ glass, $\left.\lambda_{\mathrm{ex}}=380 \mathrm{~nm}\right)$.

Transient absorption (TA) spectroscopy was also conducted (using a pump wavelength of $266 \mathrm{~nm}$ ) on the complexes under the same solvent conditions as 
described above for the UV-vis. and luminescence measurements. The spectral appearance of all six samples is very similar (Figure S2, ESI) with a bleach (or reduction) in optical density (OD) at $\lambda \sim 310 \mathrm{~nm}$ and three positive features at $\lambda \sim$ 380,490 and $760 \mathrm{~nm}$. Closer inspection of the individual peaks shows very little variation in wavelength position across the six complexes. Time-resolved analysis of the transient features at $\lambda \square=380 \mathrm{~nm}$ give life time s thatcompare well, both in magnitude and trend, to those obtained in the luminescence studies.

Analysis of the time-resolved decay of the peaks at $\lambda=760 \mathrm{~nm}$ for each sample revealed similar lifetimes, each of which correlates reasonably well with their respective lifetimes at $\lambda=380 \mathrm{~nm}$. These TA spectral features could, therefore, originate from the same excitation and intersystem crossing processes that produce the emissive ${ }^{3} \mathrm{MLCT}$ states and, based on the state lifetimes, suggest excited states for the series of complexes that are very similar in nature. ${ }^{[22]}$ Careful analysis of the features at $\lambda=760 \mathrm{~nm}$ suggest that this peak has two underlying components and is a doublet. The data is conveniently presented as a 3D contour plot (Figure 6) for $\left[\operatorname{Ir}(\mathrm{ppz}-3)_{2}\right.$ (bipy)]BF4. Additional TA spectra (including decay fits) are shown in the ESI (Figures S2 and S3).
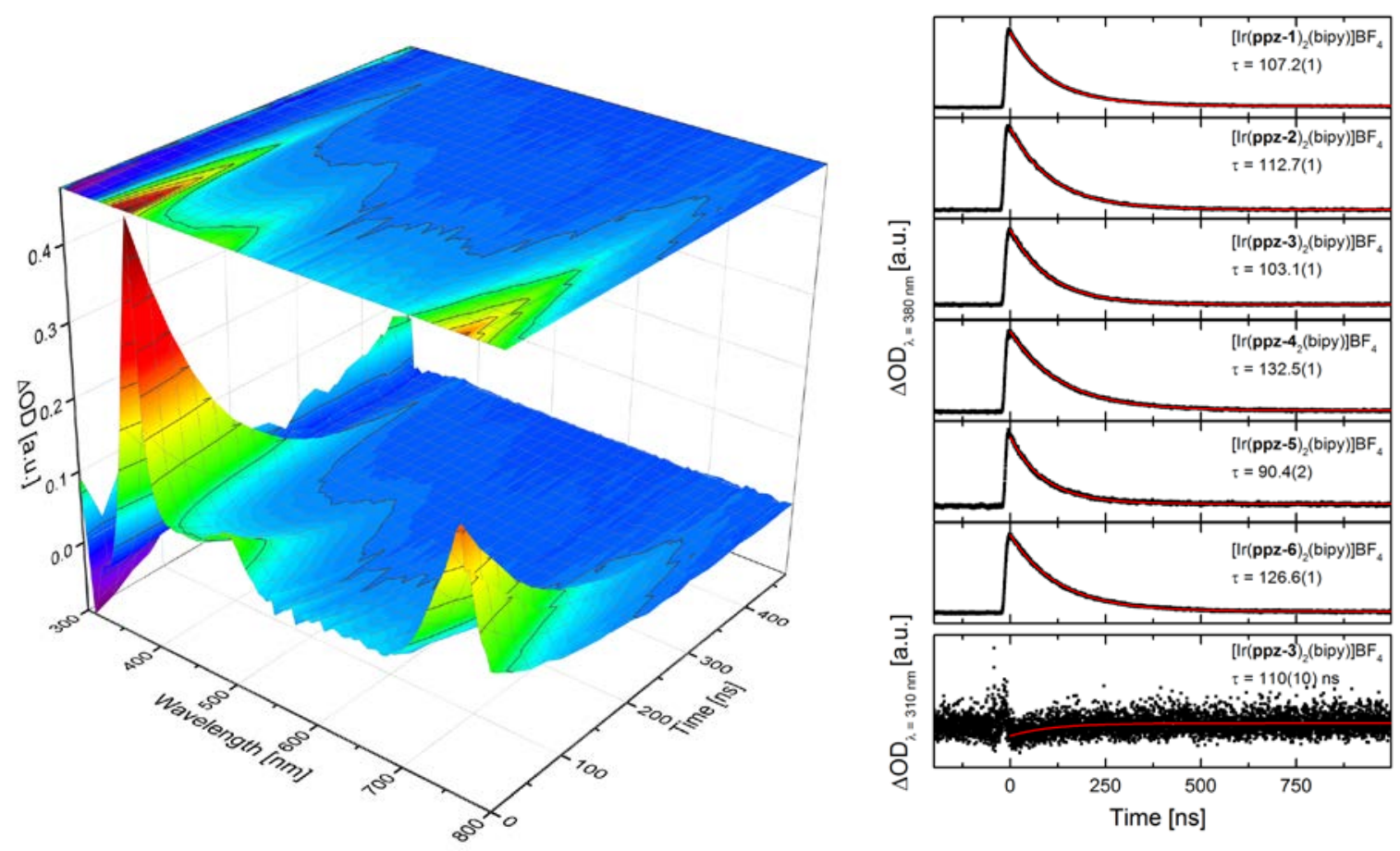

Figure 6. Transient absorption spectra and data. Left: a 3D time-resolved plot for [Ir(ppz3) ${ }_{2}$ (bipy)]BF 4 . Right: fitted (red trace) lifetime profiles for the different Ir'III complexes. The lowest panel shows, as an exemplar, the recovery of the spectral feature assigned as a bleach at $\lambda=310 \mathrm{~nm}$ for $\left[\operatorname{Ir}(\mathrm{ppz}-3)_{2}\left(\right.\right.$ bipy) $\mathrm{BF}_{4}$. The recovery of the bleach occurs on a timescale similar to the decay of the absorption features at longer wavelengths.

The electrochemical characteristics of the six $\left[\operatorname{Ir}(\mathrm{ppz})_{2}(\mathrm{bipy}) \mathrm{BF}_{4} \mathrm{Complexes}\right.$ (Table 3) were studied in de-oxygenated dichloromethane. The cyclic voltammograms were measured using a platinum disc electrode (scan rate $U=200 \mathrm{mV} \mathrm{s}^{-1}, 1 \times 10^{-3} \mathrm{M}$ 
solutions, $0.1 \mathrm{M}\left[\mathrm{NBu}_{4}\right]\left[\mathrm{PF}_{6}\right]$ as a supporting electrolyte) and each complex showed one partially or fully reversible oxidation (Table 3 ) at +1.47 to $+1.75 \mathrm{~V}$ ) ascribed to the $\mid r^{11 / / I V}$ couple. Each complex also showed one partially reversible or irreversible reduction wave, which was assigned to a ligand-centred process. The small differences in $E_{\text {ox }}$ are likely due to the nature of the substituent on the cyclometalating ligand that can influence the electron density at the iridium centre. For example, $\left[\operatorname{Ir}(\mathrm{ppz}-5)_{2}\right.$ (bipy)]BF 4 showed the lowest $E_{\text {ox }}$ value in the series, suggesting that para-fluorination of the pyrazole ligands renders the $\mathrm{Ir}$ III more easily oxidisable. The pentafluorosulfanyl derived complexes gave the highest oxidation potentials. Using the oxidation (IIII//IV) potential gave the HOMO energy levels (Eномо), from which ELuмо was also determined. The calculated $E_{\text {bandgap }}$ values again revealed a lowest value for $\left[\operatorname{Ir}(\mathrm{ppz}-5)_{2}(\right.$ bipy) $] \mathrm{BF}_{4}$, with both $\left[\operatorname{Ir}(\mathrm{ppz}-4)_{2}(\right.$ bipy)$] \mathrm{BF}_{4}$ and $\left[\operatorname{Ir}(\mathrm{ppz}-6)_{2}(\right.$ bipy)$] \mathrm{BF}_{4}$ at the largest values, which was supported by TD-DFT.

\section{Conclusions}

In conclusion, this paper demonstrates a machine-assisted technology for the rapid synthesis of luminescent ligand-metal complexes with desirable and tuneable photophysical properties. The approach provides improvements on safety, versatility and time. From a synthetic perspective, we anticipate that future improvements could emanate from connecting the two production phases (ligand and complex) into one machine (which would likely require an automated purification phase at the connecting junction) and include the ability to automatically screen the luminescent properties of the formed products. A third-generation approach could then use feedback and optimisation algorithms to deliver a discovery platform for the rapid generation of new metal-ligand materials with tuneable and targeted electronic properties. Further studies will explore the application of these, and future generations of, IrII complex as photoredox catalysts, as well as considering their deployment in bioimaging studies which can exploit the tunability of the luminescence properties.

\section{Experimental}

\section{General Experimental Considerations}

All reagents and solvents were commercially available and were used without further purification if not stated otherwise. Petroleum ether refers to the $40-60{ }^{\circ} \mathrm{C}$ fraction. For the measurement of ${ }^{1} \mathrm{H},{ }^{13} \mathrm{C}$ and ${ }^{19} \mathrm{~F}$ NMR spectra a Bruker Fourier ${ }^{300}(250,300 \mathrm{MHz})$, 400 UltraShield $^{\mathrm{TM}}(400 \mathrm{MHz})$ or Ascend ${ }^{\mathrm{TM}} 500(500 \mathrm{MHz})$ was used. The obtained chemical shifts $\delta$ are reported in ppm and are referenced to the residual solvent signal. ${ }^{19} \mathrm{~F}$ NMR signals are reported uncorrected. Spin-spin coupling constants $J$ are given in $\mathrm{Hz}$.

The flow setup consisted of perfluoroalkoxy (PFA) tubing of an $0.8 \mathrm{~mm}$ ID and two syringe and two Knauer pumps. The residence coils were made from the tubing by taking the appropriate length for the desired volume. The microwave used was a CEM Discover SP. Column chromatography was performed using 60 A (40-64 micron) silica and solvent mixtures of petroleum ether and ethyl acetate.

Low-resolution mass spectra were obtained by the staff at Cardiff University. High-resolution mass spectra were carried out at the EPSRC National Mass 
Spectrometry Facility at Swansea University. High resolution mass spectral (HRMS) data were obtained on a Waters MALDI-TOF $m x$ at Cardiff University or on a Thermo Scientific LTQ Orbitrap XL by the EPSRC UK National Mass Spectrometry Facility at Swansea University. IR spectra were obtained from a Shimadzu IR-Affinity-1S FTIR and melting points using a Gallenkamp apparatus and are reported uncorrected. Reference to spectroscopic data are given for known compounds. UV-Vis studies were performed on a Jasco $\mathrm{V}-570$ spectrophotometer as MeCN solutions (2.5 or $5 \times$ $\left.10^{-5} \mathrm{M}\right)$. Photophysical data were obtained on a JobinYvon-Horiba Fluorolog spectrometer fitted with a JY TBX picosecond photodetection module as MeCN solutions. Emission spectra were uncorrected and excitation spectra were instrument corrected. The pulsed source was a Nano-LED configured for $459 \mathrm{~nm}$ output operating at $1 \mathrm{MHz}$. Luminescence lifetime profiles were obtained using the JobinYvon-Horiba FluoroHub single photon counting module and the data fits yielded the lifetime values using the provided DAS6 deconvolution software. Quantum yield measurements were obtained on aerated MeCN solutions of the complexes using $\left[\mathrm{Ru}(\mathrm{bpy})_{3}\right]\left(\mathrm{PF}_{6}\right)_{2}$ in aerated $\mathrm{MeCN}$ as a standard $(\Phi=0.016) .{ }^{[23]}$

\section{X-ray Diffraction}

For both samples, a suitable crystal ${ }^{[24]}$ was selected and mounted on a MITIGEN holder in oil on a Rigaku FRE+ (45.0 kV, $55.0 \mathrm{~mA})$ equipped with HF Varimax confocal

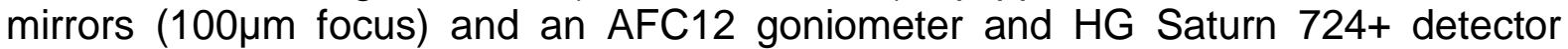
diffractometer. The crystals were kept at $T=100(2) \mathrm{K}$ during data collection. Data were measured using profile data from $\omega$-scans using $\mathrm{MoK}_{\alpha}$ radiation. Cell determination and data collection were carried out using CrystalClear ${ }^{[25]}$. With the data reduction, cell refinement and absorption correction using CrystalisPro [26]. Using Olex2 [27], the structures were solved with the ShelXT [28] structure solution program and the models were refined with version 2014/7 of ShelXL [29] using Least Squares minimisation. All non-hydrogen atoms were refined anisotropically. Hydrogen atom positions were calculated geometrically and refined using the riding model.

For sample $\left[\operatorname{lr}(\mathrm{ppz}-3)_{2}(\mathrm{bpy})\right] \mathrm{BF}_{4}$, the $\mathrm{BF}_{4}$ anions are disordered over symmetry sites and each contributes half an ion to the asymmetric unit. Also one of the $\mathrm{CF}_{3}$ groups is disordered over two positions. As such various geometrical (SADI, SAME, BUMP) restraints and displacement (RIGU) restraints were employed, along with displacement constraints (EADP).

For sample $\left[\operatorname{Ir}(\mathrm{ppz}-6)_{2}(\mathrm{bpy}) \mathrm{BF}_{4}\right.$, a general displacement restraint (RIGU) has been employed due to the number of readily disordered moieties in the asymmetric unit. Also there is a molecule of $\mathrm{MeCN}$ for which displacement constraints (EADP) have been employed.

\section{DFT calculations}

The geometry of all complexes was fully optimised without symmetry constraint using the B3LYP ${ }^{[30]}$ functional and a basis set consisting of $6-31 G(d)^{[31]}$ on light atoms with Stuttgart-Dresden core potential and basis set on Ir. ${ }^{[32]}$ Frontier orbital properties were calculated with the same functional and a $6-31+G(d, p)^{[33]}$ basis on light atoms. TDDFT used the CAM-B3LYP functional [34] known to perform well for charge transfer transitions, with $6-31+G(d, p)$ on light atoms and Stuttgart-Dresden potential/basis on Ir. All DFT calculations were performed using the Gaussian09 package. ${ }^{[35]}$ 


\section{Transient Absorption}

Transient absorption (TA) UV-Vis spectra were collected at Cardiff University using an Edinburgh Instruments LP920 laser flash photolysis spectrometer. All spectra were generated by exciting the samples (prepared as for UV-Vis studies described above) at $266 \mathrm{~nm}$ ( $4^{\text {th }}$ harmonic of a Continuum Surelite II Nd:YAG laser, operated at $10 \mathrm{~Hz}$ ) and collecting subsequent transient absorption spectra between $300 \mathrm{~nm}<\lambda \square<800$ $\mathrm{nm}$ (a Xenon lamp provides probe wavelengths). Wavelength dependent TA data was recorded in $5 \mathrm{~nm}$ steps using an in-built monochromator, with a bandwidth of $1 \mathrm{~nm}$. Data presented in this manuscript show early time spectra ( $t<1 \mu$ s post excitation), however no additional TA features were observed over longer timescales $(t<10 \mathrm{~ms})$. TA spectra are presented as $\triangle O D$ xenon lamp, hereafter simply referred to as $\triangle O D$, constructed by averaging the first $50 \mathrm{~ns}$ of data after the pump laser pulse. Lifetime data was created by fitting the raw experimental data using the Origin 2015 software package. Each fit is created using a single exponential decay function, with no evidence for multiexponential components.

\section{Electrochemistry}

Electrochemical studies were carried out using a Parstat 2273 potentiostat in conjunction with a three-electrode cell. The auxiliary electrode was a platinum wire and the working electrode a platinum $(1.0 \mathrm{~mm}$ diameter) disc. The reference was a silver wire separated from the test solution by a fine porosity frit and an agar bridge saturated with $\mathrm{KCl}$. Solutions $\left(10 \mathrm{ml} \mathrm{CH}_{2} \mathrm{Cl}_{2}\right)$ were $1.0 \times 10^{-3} \mathrm{~mol} \mathrm{dm}^{-3}$ in the test compound and $0.1 \mathrm{~mol} \mathrm{dm}^{-3}$ in $\left[\mathrm{NBu}^{n} 4\right]\left[\mathrm{PF}_{6}\right]$ as the supporting electrolyte. Under these conditions, $E^{0 \prime}$ for the one-electron oxidation of $\left[\mathrm{Fe}\left(\eta-\mathrm{C}_{5} \mathrm{H}_{5}\right)_{2}\right]$, added to the test solutions as an internal calibrant, is $+0.46 \mathrm{~V}$. ${ }^{[36]}$ Unless specified, all electrochemical values are at $U=200 \mathrm{mV} \mathrm{s}^{-1}$.

\section{Synthesis}

\section{General Procedure 1 (GP1): Preparation of fluorinated pyrazole ligands in batch and microwave}

To a solution of the aniline ( $3 \mathrm{mmol})$ in $\mathrm{MeCN}(5 \mathrm{~mL})$ in a $35 \mathrm{~mL}$ microwave vial $\mathrm{HCl}$ ( $3 \mathrm{~mL}, 1 \mathrm{M}, 3 \mathrm{mmol}, 1$ equiv) in water $(5 \mathrm{~mL})$ was added. After cooling the solution to $0{ }^{\circ} \mathrm{C}$ isoamylnitrite $(0.351 \mathrm{~g}, 3 \mathrm{mmol}, 1$ equiv) in MeCN $(5 \mathrm{~mL})$ was added dropwise. Then ascorbic acid ( $0.528 \mathrm{~g}, 3 \mathrm{mmol}, 1$ equiv) was added neat and another $5 \mathrm{~mL}$ water added. The solution was stirred for $30 \mathrm{~min}$ at room temperature. 2,4Pentanedione ( $0.600 \mathrm{~g}, 6 \mathrm{mmol}, 2$ equiv) was added neat and the reaction solution heated in the microwave for $30 \mathrm{~min}$ at $140{ }^{\circ} \mathrm{C}$. To the crude reaction mixture was added $10 \mathrm{~mL}$ of aqueous $\mathrm{NaHCO}_{3}$ before the product was extracted ( $3 \times 25 \mathrm{~mL}$ $\left.\mathrm{CH}_{2} \mathrm{Cl}_{2}\right)$. The combined organic layers were washed with brine $(25 \mathrm{~mL})$, dried over $\mathrm{MgSO}_{4}$ and concentrated in vacuo to give the crude product. This was further purified via column chromatography (0 to $10 \%$ EtOAc in petroleum ether) to yield the product.

Synthesis of 3,5-dimethyl-1-(4-(trifluoromethoxy)phenyl)-1H-pyrazole (ppz-1) 
Following the general procedure (GP1) with 4-(trifluoromethoxy)aniline (0.503 g, $3 \mathrm{mmol}$ ) the product, 3,5-dimethyl-1-(4-(trifluoromethoxy)phenyl)-1H-pyrazole, was obtained as a brown oil $(55 \%, 0.841 \mathrm{~g}, 3.3 \mathrm{mmol}) .{ }^{1} \mathrm{H}$ NMR $\left(400 \mathrm{MHz}, \mathrm{CDCl}_{3}, 25^{\circ} \mathrm{C}\right)$ : $\delta=7.46(\mathrm{~d}, \mathrm{~J}=7.5 \mathrm{~Hz}, 2 \mathrm{H}), 7.29(\mathrm{~d}, \mathrm{~J}=8.2 \mathrm{~Hz}, 2 \mathrm{H}), 6.00(\mathrm{~s}, 1 \mathrm{H}), 2.31(\mathrm{~s}, 3 \mathrm{H}), 2.29$ (s, 3H) ppm; ${ }^{13} \mathrm{C}\left\{{ }^{1} \mathrm{H}\right\}$ NMR $\left(126 \mathrm{MHz}, \mathrm{CDCl}_{3}, 25^{\circ} \mathrm{C}\right): \delta=149.5,147.0,139.5,138.5$, 126.0, 121.5, 120.5 (q, $\mathrm{J}=258 \mathrm{~Hz}), 107.5,13.5,12.5$ ppm; ${ }^{19} \mathrm{~F}$ NMR $\left(376 \mathrm{MHz}, \mathrm{CDCl}_{3}\right.$, $25^{\circ} \mathrm{C}$ ): $\delta=-58.00$ (s) ppm; IR: 2928, 1558, 1514, 1252, 1202, 1155, $853 \mathrm{~cm}^{-1}$; HRMS (FTMS + p NSI): m/z: 257.0896, calc. 257.0894 for $\left[M^{+}+\mathrm{H}\right]$.

\section{Synthesis of 1-(3-(trifluoromethyl)phenyl)-3,5-dimethyl-1H-pyrazole (ppz-2)}

Following the general procedure (GP1) with 3-(trifluoromethyl)aniline $(0.483 \mathrm{~g}$, $3 \mathrm{mmol}$ ) the product, 1-(3-(trifluoromethyl)phenyl)-3,5-dimethyl-1H-pyrazole, was obtained as a yellow oil (62\%, $0.446 \mathrm{~g}, 1.86 \mathrm{mmol}) .{ }^{1} \mathrm{H}$ NMR $\left(500 \mathrm{MHz}, \mathrm{CDCl}_{3}, 25^{\circ} \mathrm{C}\right)$ : $\delta=7.74(\mathrm{~s}, 1 \mathrm{H}), 7.68-7.53(\mathrm{~m}, 3 \mathrm{H}), 6.03(\mathrm{~s}, 1 \mathrm{H}), 2.34(\mathrm{~s}, 3 \mathrm{H}), 2.30(\mathrm{~s}, 3 \mathrm{H}) \mathrm{ppm}$; ${ }^{13} \mathrm{C}\left\{{ }^{1} \mathrm{H}\right\}$ NMR $\left(126 \mathrm{MHz}, \mathrm{CDCl}_{3}, 25^{\circ} \mathrm{C}\right): \delta=145.0,140.5,139.5,132.0(\mathrm{q}, \mathrm{J}=32.8 \mathrm{~Hz})$, 129.5, 127.5, 124.0 (q, $J=3.6 \mathrm{~Hz}), 123.5$ (q, $J=272.5 \mathrm{~Hz}), 121.5$ (q, $J=3.8 \mathrm{~Hz})$, 108.0, 13.5, 12.5 ppm; ${ }^{19} \mathrm{~F}$ NMR (376 MHz, $\left.\mathrm{CDCl}_{3}, 25^{\circ} \mathrm{C}\right): \delta=-62.68$ (s) ppm; IR: 2978, 1597, 1562, 1497,1454, 1381, 1366, 1327, 1165, 1123, 1069, 895, 799, $698 \mathrm{~cm}^{-1}$; HRMS (ASAP+): $m / z$ : 241.0953, calc. 241.0953 for $\left[M^{+}+H\right]$.

\section{Synthesis of 1-(4-(trifluoromethyl)phenyl)-3,5-dimethyl-1H-pyrazole (ppz-3)}

Following the general procedure (GP1) with 4-(trifluoromethyl)aniline (0.483 g, $3 \mathrm{mmol}$ ) the product, 1-(4-(trifluoromethyl)phenyl)-3,5-dimethyl-1H-pyrazole, was obtained as a yellow oil $(74 \%, 0.532 \mathrm{~g}, 2.23 \mathrm{mmol}) .{ }^{1} \mathrm{H}$ NMR $\left(400 \mathrm{MHz}, \mathrm{CDCl}_{3}, 25^{\circ} \mathrm{C}\right)$ : $\delta=7.71(\mathrm{~d}, \mathrm{~J}=8.0 \mathrm{~Hz}, 2 \mathrm{H}), 7.59(\mathrm{~d}, \mathrm{~J}=8.1 \mathrm{~Hz}, 2 \mathrm{H}), 6.04(\mathrm{~s}, 1 \mathrm{H}), 2.36(\mathrm{~s}, 3 \mathrm{H}), 2.30$ (s, 3H) ppm; ${ }^{13} \mathrm{C}\left\{{ }^{1} \mathrm{H}\right\}$ NMR $\left(126 \mathrm{MHz}, \mathrm{CDCl}_{3}, 25^{\circ} \mathrm{C}\right): \delta=150.0,143.0,139.5,129.0$ (q, $\mathrm{J}=32.8 \mathrm{~Hz}$ ), 126.5 (q, $\mathrm{J}=3.5 \mathrm{~Hz}), 124.5,124.0$ (q, $\mathrm{J}=272.0 \mathrm{~Hz}), 108.5,13.5,13.0$ ppm; $\left.{ }^{19} \mathrm{~F} \mathrm{NMR} \mathrm{(376} \mathrm{MHz,} \mathrm{CDCl}_{3}, 25^{\circ} \mathrm{C}\right): \delta=-62.34$ (s) ppm; IR: 2928, 1614, 1321, 1119, 1067, 843, $457 \mathrm{~cm}^{-1}$; HRMS (FTMS + p NSI): m/z: 241.0947, calc. 241.0944 for $\left[M^{+}+\mathrm{H}\right]$.

\section{Synthesis of 1-(3-pentafluorothio)-3,5-dimethyl-1H-pyrazole (ppz-4)}

Following the general procedure (GP1) with 3-(pentafluorothio)aniline (0.483 $\mathrm{g}$, $2 \mathrm{mmol}$ ) the product, 1-(3-pentafluorothio)-3,5-dimethyl-1H-pyrazole, was obtained as a yellow oil $(70 \%, 0.417 \mathrm{~g}, 1.4 \mathrm{mmol}) .{ }^{1} \mathrm{H}$ NMR $\left(400 \mathrm{MHz}, \mathrm{CDCl}_{3}, 25^{\circ} \mathrm{C}\right): \delta=7.87(\mathrm{~s}$, $1 \mathrm{H}), 7.72(\mathrm{~d}, \mathrm{~J}=8.1 \mathrm{~Hz}, 1 \mathrm{H}), 7.62(\mathrm{~d}, \mathrm{~J}=7.9 \mathrm{~Hz}, 1 \mathrm{H}), 7.59-7.51(\mathrm{~m}, 1 \mathrm{H}), 6.04(\mathrm{~s}$, $1 \mathrm{H}), 2.34(\mathrm{~s}, 3 \mathrm{H}), 2.30(\mathrm{~s}, 3 \mathrm{H}) \mathrm{ppm} ;{ }^{13} \mathrm{C}\left\{{ }^{1} \mathrm{H}\right\} \mathrm{NMR}\left(101 \mathrm{MHz}, \mathrm{CDCl}_{3}, 25^{\circ} \mathrm{C}\right): \delta=150.0$, $140.5,139.5,129.5,127.5,124.5$ - $124.0(\mathrm{~m}), 122.5$ - $122.0(\mathrm{~m}), 108.0,13.5,12.5$; ${ }^{19} \mathrm{~F}$ NMR $\left(376 \mathrm{MHz}, \mathrm{CDCl}_{3}, 25^{\circ} \mathrm{C}\right): \delta=84.42-82.41(\mathrm{~m}, 1 \mathrm{~F}), 63.24-62.43(\mathrm{~m}, 4 \mathrm{~F})$ ppm; IR: 2980, 1605, 1493, 829, 771, $596 \mathrm{~cm}^{-1}$. HRMS (ASAP+): m/z: 299.0664, calc. 299.0641 for $\left[M^{+}+H\right]$. 
Following the general procedure with 4-fluoroaniline $(0.333 \mathrm{~g}, 3 \mathrm{mmol})$ the product, 1(4-fluorophenyl)-3,5-dimethyl-1H-pyrazole, was obtained as a yellow oil $(57 \%$, $0.566 \mathrm{~g}, 2.02 \mathrm{mmol})$. The spectroscopic data obtained matches the literature. ${ }^{[14 \mathrm{a}]}{ }^{1} \mathrm{H}$ $\operatorname{NMR}\left(400 \mathrm{MHz}, \mathrm{CDCl}_{3}, 25^{\circ} \mathrm{C}\right): \delta=7.43-7.33(\mathrm{~m}, 2 \mathrm{H}), 7.18-7.07(\mathrm{~m}, 2 \mathrm{H}), 5.98(\mathrm{~s}$, $1 \mathrm{H}), 2.28(\mathrm{~s}, 3 \mathrm{H}), 2.26(\mathrm{~s}, 3 \mathrm{H}) \mathrm{ppm} ;{ }^{13} \mathrm{C}\left\{{ }^{1} \mathrm{H}\right\} \mathrm{NMR}\left(126 \mathrm{MHz}, \mathrm{CDCl}_{3}, 25^{\circ} \mathrm{C}\right): \delta=161.5$ $(\mathrm{d}, \mathrm{J}=247.0 \mathrm{~Hz}), 149.0,139.5,136.0(\mathrm{~d}, \mathrm{~J}=2.8 \mathrm{~Hz}), 127.0(\mathrm{~d}, \mathrm{~J}=8.6 \mathrm{~Hz}), 116.0(\mathrm{~d}$, $\mathrm{J}=22.8 \mathrm{~Hz}), 107.0,13.5,12.5 \mathrm{ppm} ;{ }^{19} \mathrm{~F} \mathrm{NMR}\left(471 \mathrm{MHz}, \mathrm{CDCl}_{3}, 25^{\circ} \mathrm{C}\right): \delta=-114 \mathrm{ppm}$; IR: 2924, 1557, 1510, 1383, 1219, 837, $610 \mathrm{~cm}^{-1}$. HRMS (FTMS + p NSI): $\mathrm{m} / \mathrm{z}$ : 191.0975, calc. 191.0979 for $\left[M^{+}+\mathrm{H}\right]$.

\section{Synthesis of 1-(4-pentafluorothio)-3,5-dimethyl-1H-pyrazole (ppz-6)}

Following the general procedure (GP1) with 4-(pentafluorothio)aniline (0.438 $\mathrm{g}$, $2 \mathrm{mmol}$ ) the product, 1-(4-pentafluorothio)-3,5-dimethyl-1H-pyrazole, was obtained as a yellow solid $(73 \%, 0.435 \mathrm{~g}, 1.46 \mathrm{mmol})$. The spectroscopic data obtained matches the literature. ${ }^{[14 \mathrm{a}]}{ }^{1} \mathrm{H}$ NMR $\left(400 \mathrm{MHz}, \mathrm{CDCl}_{3}, 25^{\circ} \mathrm{C}\right): \delta=7.83(\mathrm{~d}, \mathrm{~J}=8.4 \mathrm{~Hz}, 2 \mathrm{H}), 7.57$ $(\mathrm{d}, \mathrm{J}=8.6 \mathrm{~Hz}, 2 \mathrm{H}), 6.05(\mathrm{~s}, 1 \mathrm{H}), 2.38(\mathrm{~s}, 3 \mathrm{H}), 2.30(\mathrm{~s}, 3 \mathrm{H}) \mathrm{ppm} ;{ }^{13} \mathrm{C}\left\{{ }^{1} \mathrm{H}\right\}$ NMR $(126$ $\left.\mathrm{MHz}_{2} \mathrm{CDCl}_{3}, 25^{\circ} \mathrm{C}\right): \delta=152.0-151.5(\mathrm{~m}), 150.5,142.5,140.0,127.5-126.5(\mathrm{~m})$, 123.5, 108.5, 13.5, $13.0 \mathrm{ppm} ;{ }^{19} \mathrm{~F}$ NMR (376 MHz, $\left.\mathrm{CDCl}_{3}, 25^{\circ} \mathrm{C}\right): \delta=85.17-83.13(\mathrm{~m}$, 1F), 63.68 - 62.92 (m, 4F) ppm; IR: 2980, 1555, 1503, 1366, 808, 789, 768, 660, $575 \mathrm{~cm}^{-1}$; HRMS (ASAP+): $\mathrm{m} / \mathrm{z}$ : 299.0648, calc. 299.0641 for $\left[M^{+}+\mathrm{H}\right]$.

\section{General Procedure 2 (GP2): Preparation of fluorinated pyrazole ligands in flow and microwave ${ }^{[14 a]}$}

Solutions of the aniline $(0.2 \mathrm{M}$ in acetonitrile $), \mathrm{HCl}(0.2 \mathrm{M}$ in water), isoamylnitrite ( $0.2 \mathrm{M}$ in acetonitrile) and ascorbic acid ( $0.2 \mathrm{M}$ in acetonitrile) were prepared. The solutions were then pumped through the flow system (see Scheme S1 and S2) at a flow rate of $0.2 \mathrm{mLmin}^{-1}$. After 20 min steady state was presumed reached and $20 \mathrm{~mL}$ ( $1 \mathrm{mmol}, 25 \mathrm{~min}$ ) of the resulting reaction mixture was collected and transferred into a microwave vial equipped with a stirrer bar and 2,4-pentadione $(0.200 \mathrm{~g}, 2 \mathrm{mmol}, 2$ equiv). The mixture was heated to $140{ }^{\circ} \mathrm{C}$ for $30 \mathrm{~min}$ in the microwave. After cooling to room temperature, the reaction mixture was quenched with $10 \mathrm{~mL} \mathrm{NaHCO}_{3}$, extracted with $\mathrm{CH}_{2} \mathrm{Cl}_{2}(3 \times 20 \mathrm{~mL})$, washed with brine and dried over $\mathrm{MgSO}_{4}$. After removing the solvent under reduced pressure the crude product was further purified by column chromatography to give the desired product.

Synthesis of 3,5-dimethyl-1-(4-(trifluoromethoxy)phenyl)-1H-pyrazole (ppz-1)

Following the general procedure (GP2), 3,5-dimethyl-1-(4-(trifluoromethoxy)phenyl)$1 \mathrm{H}$-pyrazole was obtained as a brown oil $(70 \%, 0.180 \mathrm{~g})$.

Synthesis of 1-(3-(trifluoromethyl)phenyl)-3,5-dimethyl-1H-pyrazole (ppz-2)

Following the general procedure (GP2), 1-(3-(trifluoromethyl)phenyl)-3,5-dimethyl-1Hpyrazole was obtained as a yellow oil $(48 \%, 0.116 \mathrm{~g})$. 
Synthesis of 1-(4-(trifluoromethyl)phenyl)-3,5-dimethyl-1H-pyrazole (ppz-3)

Following the general procedure (GP2), 1-(4-(trifluoromethyl)phenyl)-3,5-dimethyl-1Hpyrazole was obtained as a yellow oil $(84 \%, 0.202 \mathrm{~g})$.

Synthesis of 1-(3-pentafluorothio)-3,5-dimethyl-1H-pyrazole (ppz-4)

Following the general procedure (GP2), 1-(3-pentafluorothio)-3,5-dimethyl-1Hpyrazole was obtained as a yellow oil $(72 \%, 0.137 \mathrm{~g})$.

Synthesis of 1-(4-fluorophenyl)-3,5-dimethyl-1H-pyrazole (ppz-5)

Following the general procedure (GP2), 1-(4-fluorophenyl)-3,5-dimethyl-1H-pyrazole was obtained as a yellow oil $(57 \%, 0.566 \mathrm{~g})$.

Synthesis of 1-(4-pentafluorothio)-3,5-dimethyl-1H-pyrazole (ppz-6)

Following the general procedure (GP2), 1-(4-pentafluorothio)-3,5-dimethyl-1Hpyrazole was obtained as a yellow solid $(62 \%, 0.186 \mathrm{~g})$.

\section{General Procedure 3 (GP3): Preparation of fluorinated pyrazole-Iridium complexes in batch as exemplified by the synthesis of $\left[\operatorname{Ir}(p p z-1)_{2}(\right.$ bipy $\left.)\right] B F_{4}$}

IrCl $3 . x \mathrm{H}_{2} \mathrm{O}(180 \mathrm{mg}, 0.6 \mathrm{mmol})$, ppz-1 (310 mg, $\left.1.2 \mathrm{mmol}\right)$ and $\mathrm{H}_{2} \mathrm{O}(2 \mathrm{~mL})$ were heated at reflux in 2-methoxyethanol $(6 \mathrm{~mL})$ under argon for 48 hours. The solution was cooled and $\mathrm{H}_{2} \mathrm{O}$ added $(\sim 20 \mathrm{~mL})$. The resulting grey precipitate was filtered and oven dried to give presumed chloro-bridged dimer $\left[\operatorname{Ir}(\mathrm{ppz}-1)_{2}(\mu-\mathrm{Cl})_{2}(\mathrm{ppz}-1)_{2}\right]$. The dimer $\left[\operatorname{lr}(\mathrm{ppz}-1)_{2}(\mu-\mathrm{Cl})_{2}(\mathrm{ppz}-1)_{2}\right](100 \mathrm{mg}, 0.07 \mathrm{mmol})$ was split by stirring for 2 hours at reflux in the presence of $\mathrm{AgBF}_{4}(27 \mathrm{mg}, 0.14 \mathrm{mmol})$ with MeCN $(15 \mathrm{~mL})$ as solvent. The solution was cooled, filtered through cotton wool and the solvent removed in vacuo. The crude complex was precipitated from minimal dichloromethane and hexane as a grey oil, $\left[\operatorname{Ir}(\mathrm{ppz}-1)_{2}(\mathrm{MeCN})_{2}\right] \mathrm{BF}_{4}$. The $\left[\operatorname{Ir}(\mathrm{ppz}-1)_{2}(\mathrm{MeCN})_{2}\right] \mathrm{BF}_{4}(140 \mathrm{mg}$, $0.16 \mathrm{mmol}$ ) and 2,2'-bipyridine (26 mg, $0.16 \mathrm{mmol}$ ) were dissolved in $\mathrm{CHCl}_{3}(7 \mathrm{ml})$ and heated at reflux under argon for 24 hours. The solution was cooled and the solvent removed in vacuo. The crude solid was dissolved in minimal dichloromethane and added drop wise to stirring $\mathrm{Et}_{2} \mathrm{O}(15 \mathrm{~mL})$ at $0^{\circ} \mathrm{C}$. The resultant precipitate was filtered to give $\left[\operatorname{Ir}(\mathrm{ppz}-1)_{2}(\mathrm{bipy})\right] \mathrm{BF}_{4}$ as a yellow solid $(91 \mathrm{mg}, 60 \%) .{ }^{1} \mathrm{H} \mathrm{NMR}\left(500 \mathrm{MHz}, \mathrm{CDCl}_{3}\right.$, $\left.25^{\circ} \mathrm{C}\right): \delta=8.86\left(\mathrm{~d},{ }^{3} \mathrm{JHH}=8.2 \mathrm{~Hz}, 2 \mathrm{H}\right), 8.17\left(\mathrm{t},{ }^{3} \mathrm{~J}_{\mathrm{HH}}=7.8 \mathrm{~Hz}, 2 \mathrm{H}\right), 7.80\left(\mathrm{~d},{ }^{3} \mathrm{~J}_{\mathrm{HH}}=5.2\right.$ $\mathrm{Hz}, 2 \mathrm{H}), 7.41-7.36(\mathrm{~m}, 4 \mathrm{H}), 6.86\left(\mathrm{~d},{ }^{3} \mathrm{~J}_{\mathrm{HH}}=8.1 \mathrm{~Hz}, 2 \mathrm{H}\right), 6.00(\mathrm{~s}, 2 \mathrm{H}), 5.96(\mathrm{~s}, 2 \mathrm{H})$, $2.73(\mathrm{~s}, 6 \mathrm{H}), 1.39(\mathrm{~s}, 6 \mathrm{H}) \mathrm{ppm} ;{ }^{13} \mathrm{C}\left\{{ }^{1} \mathrm{H}\right\} \mathrm{NMR}\left(100 \mathrm{MHz}, \mathrm{CDCl}_{3}, 25^{\circ} \mathrm{C}\right): \delta=156.3,150.2$, 149.6, 146.1, 142.6, 141.5, 140.3, 135.0, 127.9, 125.6, 124.9, 115.2, 113.2, 110.6, 14.2, 12.0 ppm; IR (solid): $v$ bar $=2976,2359,1607,1574,1558,1472,1445,1248$, $1217,1186,1155,1053,804,768,664,588,521,449 \mathrm{~cm}^{-1}$; UV-vis (MeCN): $\lambda_{\max }(\varepsilon)$ 
= 340 (6800) sh, 310 (18300) sh, 297 (24400), 252 nm (51000 M-1 $\left.\mathrm{cm}^{-1}\right) ;$ HRMS: m/z: 859.1786, calc. 859.1802 for $\left[M^{+}-B_{4}\right]$.

\section{Synthesis of $\left[\operatorname{Ir}(\mathbf{p p z}-2)_{2}\left({\text { bipy })] B F_{4}}_{4}\right.\right.$}

Following the general procedure (GP3), with $\mathrm{IrCl}_{3} . \mathrm{xH}_{2} \mathrm{O}(156 \mathrm{mg}, 0.53 \mathrm{mmol})$ and ppz2 (252 mg, $1.05 \mathrm{mmol})$. [ $\left.\operatorname{lr}(\mathrm{ppz}-2)_{2}(\mathrm{bipy})\right] \mathrm{BF}_{4}$ was isolated as a light yellow solid (130 $\mathrm{mg}, 84 \%) .{ }^{1} \mathrm{H}$ NMR $\left(400 \mathrm{MHz}\right.$, [D6]acetone, $\left.25^{\circ} \mathrm{C}\right): \delta=8.91\left(\mathrm{~d},{ }^{3} \mathrm{~J}_{\mathrm{HH}}=8.2 \mathrm{~Hz}, 2 \mathrm{H}\right), 8.37$ (app. td, $\left.\mathrm{J}_{\mathrm{HH}}=8.0,1.5 \mathrm{~Hz}, 2 \mathrm{H}\right), 8.19\left(\mathrm{~d},{ }^{3} \mathrm{~J}_{\mathrm{HH}}=4.5 \mathrm{~Hz}, 2 \mathrm{H}\right), 7.82(\mathrm{~s}, 2 \mathrm{H}), 7.76-7.70$ $(\mathrm{m}, 2 \mathrm{H}), 7.14\left(\mathrm{~d},{ }^{3} \mathrm{~J}_{\mathrm{HH}}=8.1 \mathrm{~Hz}, 2 \mathrm{H}\right), 6.59\left(\mathrm{~d},{ }^{3} \mathrm{~J}_{\mathrm{HH}}=7.9 \mathrm{~Hz}, 2 \mathrm{H}\right), 6.40(\mathrm{~s}, 2 \mathrm{H}), 2.98$ $(\mathrm{s}, 6 \mathrm{H}), 1.63(\mathrm{~s}, 6 \mathrm{H}) \mathrm{ppm} ;{ }^{13} \mathrm{C}\left\{{ }^{1} \mathrm{H}\right\}$ NMR $\left(100 \mathrm{MHz}\right.$, [D6]acetone, $\left.25^{\circ} \mathrm{C}\right): \delta=157.5$, $152.1,151.8,146.0,143.9,141.1,140.5,135.1,129.7,125.9,122.8$ (q, JCF $=3.6 \mathrm{~Hz}$ ), 112.2, 110.1 (q, JCF $=4.1 \mathrm{~Hz}), 14.4,12.4$ ppm; IR (solid): $v$ bar = 2979, 2359, 1605, 1557, 1429, 1294,1327, 1159, 1119, 1082, 1051, 1026, 829, 772, 702; UV-vis (MeCN): $\lambda_{\max }(\varepsilon)=339 \mathrm{sh}(4600), 310 \mathrm{sh}(17500), 276 \mathrm{~nm}\left(30900 \mathrm{M}^{-1} \mathrm{~cm}^{-1}\right) ; \mathrm{HRMS}: \mathrm{m} / \mathrm{z}$ : 827.1887, calc. 827.1905 for $\left[M^{+}-B_{4}\right]$.

\section{Synthesis of $\left[\operatorname{Ir}(\mathbf{p p z}-3)_{2}(\right.$ bipy $\left.)\right] B_{F_{4}}$}

Following the general procedure (GP3) with $\mathrm{IrCl}_{3} . \mathrm{xH}_{2} \mathrm{O}(151 \mathrm{mg}, 0.5 \mathrm{mmol})$ and ppz$3(243 \mathrm{mg}, 1.0 \mathrm{mmol})$. [Ir( $\left.\mathrm{L}^{3}\right)_{2}$ (bipy)]BF 4 was isolated as a green/yellow solid $(100 \mathrm{mg}$, $71 \%) .{ }^{1} \mathrm{H}$ NMR $\left(400 \mathrm{MHz}\right.$, [D6]acetone, $\left.25^{\circ} \mathrm{C}\right): \delta=8.76\left(\mathrm{~d},{ }^{3} \mathrm{~J}_{\mathrm{HH}}=8.2 \mathrm{~Hz}, 2 \mathrm{H}\right), 8.22$ $\left(\mathrm{td},{ }^{3} \mathrm{~J}_{\mathrm{HH}}=8.0,1.6 \mathrm{~Hz}, 2 \mathrm{H}\right), 8.03\left(\mathrm{dd}, \mathrm{J}_{\mathrm{HH}}=5.5,0.8 \mathrm{~Hz}, 2 \mathrm{H}\right), 7.71\left(\mathrm{~d},{ }^{3} \mathrm{~J}_{\mathrm{HH}}=8.6 \mathrm{~Hz}\right.$, $2 \mathrm{H}), 7.59\left(\mathrm{ddd},{ }^{3} \mathrm{~J}_{\mathrm{HH}}=7.6,5.5,1.2 \mathrm{~Hz}, 2 \mathrm{H}\right), 7.28\left(\mathrm{dd}, \mathrm{J}_{\mathrm{HH}}=8.5,1.4 \mathrm{~Hz}, 2 \mathrm{H}\right), 6.44(\mathrm{~d}$, $\left.{ }^{3} \mathrm{~J}_{\mathrm{HH}}=1.9 \mathrm{~Hz}, 2 \mathrm{H}\right), 6.27(\mathrm{~s}, 2 \mathrm{H}), 2.80(\mathrm{~s}, 6 \mathrm{H}), 1.49(\mathrm{~s}, 6 \mathrm{H}) \mathrm{ppm} ;{ }^{13} \mathrm{C}\left\{{ }^{1} \mathrm{H}\right\}$ NMR $(100$ $\mathrm{MHz}$, [D6]acetone, $\left.25^{\circ} \mathrm{C}\right): \delta=157.5,152.4,151.7,148.5,144.4,141.0,134.6,130.1$ $\left(q, J_{C F}=3.8 \mathrm{~Hz}\right), 127.3\left(q,{ }^{1} J_{C F}=31.1 \mathrm{~Hz}\right), 125.9,121.8\left(q, J_{C F}=4.0 \mathrm{~Hz}\right), 114.2,112.0$, 14.5, 12.4 ppm; IR (solid): v bar = 2976, 1604, 1557, 1472, 1400, 1323, 1267, 1078, 1055, 897, 816, 767, 702, $648 \mathrm{~cm}^{-1}$; UV-vis (MeCN): $\lambda_{\max }(\varepsilon)=341 \mathrm{sh}(6600), 310 \mathrm{sh}$ (18700), $297 \mathrm{sh}$ (21500), $277 \mathrm{~nm}$ (32400 M-1 $\left.\mathrm{cm}^{-1}\right)$ HRMS: m/z: 827.1883, calc. 827.1905 for $\left[M^{+}-B_{4}\right]$.

\section{Synthesis of $\left[\operatorname{Ir}(\mathbf{p p z}-4)_{2}\left({\text { bipy })] B F_{4}}_{4}\right.\right.$}

Following the general procedure (GP3) with $\mathrm{IrCl}_{3} \cdot \mathrm{xH}_{2} \mathrm{O}(122 \mathrm{mg}, 0.4 \mathrm{mmol})$ and ppz4 (243 mg, $0.8 \mathrm{mmol})$. [Ir(ppz-4)2(bipy)]BF 4 was isolated as an off-white solid (116 mg, $52 \%) .{ }^{1} \mathrm{H}$ NMR $\left(400 \mathrm{MHz}\right.$, [D6]acetone, $\left.25^{\circ} \mathrm{C}\right): \delta=8.92\left(\mathrm{~d},{ }^{3} \mathrm{~J}_{\mathrm{HH}}=8.0 \mathrm{~Hz}, 2 \mathrm{H}\right), 8.38$ $\left(\mathrm{td},{ }^{3} \mathrm{~J}_{\mathrm{HH}}=8.0,1.5 \mathrm{~Hz}, 2 \mathrm{H}\right), 8.23\left(\mathrm{~d},{ }^{3} \mathrm{~J}_{\mathrm{HH}}=4.7 \mathrm{~Hz}, 2 \mathrm{H}\right), 7.97\left(\mathrm{~d},{ }^{3} \mathrm{~J}_{\mathrm{HH}}=2.1 \mathrm{~Hz}, 2 \mathrm{H}\right)$, $7.78-7.69(\mathrm{~m}, 2 \mathrm{H}), 7.31\left(\mathrm{dd}, \mathrm{J}_{\mathrm{HH}}=8.4,2.1 \mathrm{~Hz}, 2 \mathrm{H}\right), 6.59\left(\mathrm{~d},{ }^{3} \mathrm{~J}_{\mathrm{HH}}=8.3 \mathrm{~Hz}, 2 \mathrm{H}\right), 6.42$ (s, 2H), $2.97(\mathrm{~s}, 6 \mathrm{H}), 1.64(\mathrm{~s}, 6 \mathrm{H}) \mathrm{ppm} ;{ }^{13} \mathrm{C}\left\{{ }^{1} \mathrm{H}\right\}$ NMR $\left(150 \mathrm{MHz}, \mathrm{CD}_{3} \mathrm{CN}, 25^{\circ} \mathrm{C}\right): \delta=$ 157.0, 152.4, 152.0, 145.5, 144.2, 140.8, 140.5, 134.4, 129.4, 125.7, 123.1, 111.8, 111.6, 111.1, 14.4, 12.4 ppm; IR (solid): $v$ bar = 2982, 1607, 1553, 1470, 1427, 1080, 1051, 1035, 854, 833, 795, 771, 723, 656, 594, 567, $519 \mathrm{~cm}^{-1}$; UV-vis (MeCN): $\lambda_{\max }$ $(\varepsilon)=342 \mathrm{sh}$ (6300), $308 \mathrm{sh}$ (21400), $297 \mathrm{sh}$ (28300), $276 \mathrm{~nm}\left(36600 \mathrm{M}^{-1} \mathrm{~cm}^{-1}\right)$; HRMS: $\mathrm{m} / \mathrm{z}$ : 943.1254 , calc. 943.1280 for $\left[\mathrm{M}^{+}-\mathrm{BF}_{4}\right]$.

\section{Synthesis of $\left[\operatorname{Ir}(\mathbf{p p z}-5)_{2}(\right.$ bipy $\left.)\right] \mathrm{BF}_{4}$}

Following the general procedure (GP3) with $\mathrm{IrCl}_{3} . \mathrm{xH}_{2} \mathrm{O}(200 \mathrm{mg}, 0.7 \mathrm{mmol})$ and ppz5 (256 mg, $1.3 \mathrm{mmol})$. [Ir(ppz-5)2(bipy)]BF 4 was isolated as a yellow solid (121 mg, 56 
\%). ${ }^{1} \mathrm{H}$ NMR $\left(400 \mathrm{MHz}\right.$, [D6]acetone, $\left.25^{\circ} \mathrm{C}\right): \delta=8.74\left(\mathrm{~d},{ }^{3} \mathrm{~J}_{\mathrm{HH}}=8.1 \mathrm{~Hz}, 2 \mathrm{H}\right), 8.27-8.17$ $(\mathrm{m}, 2 \mathrm{H}), 8.06\left(\mathrm{~d},{ }^{3} \mathrm{~J}_{\mathrm{HH}}=4.7 \mathrm{~Hz}, 2 \mathrm{H}\right), 7.63-7.53(\mathrm{~m}, 4 \mathrm{H}), 6.70\left(\mathrm{td},{ }^{3} \mathrm{~J}_{\mathrm{HH}}=8.7,2.8 \mathrm{~Hz}\right.$, $2 \mathrm{H}), 6.16(\mathrm{~s}, 2 \mathrm{H}), 5.83\left(\mathrm{dd}, \mathrm{J}_{\mathrm{HH}}=9.0,2.9 \mathrm{~Hz}, 2 \mathrm{H}\right), 2.73(\mathrm{~s}, 6 \mathrm{H}), 1.44(\mathrm{~s}, 6 \mathrm{H}) \mathrm{ppm}$; ${ }^{13} \mathrm{C}\left\{{ }^{1} \mathrm{H}\right\}$ NMR $\left(100 \mathrm{MHz}, \mathrm{CDCl}_{3}, 25^{\circ} \mathrm{C}\right): \delta=156.6,150.0\left(\mathrm{~d}, J_{\mathrm{CF}}=13.7 \mathrm{~Hz}\right), 141.0$, 140.6, 128.0, 125.9, 120.1, 119.9, 113.8, 113.7, 110.7, 110.0, 109.7, 14.6, 12.4 ppm; IR (solid): $v$ bar $=1603,1574,1553,1472,1441,1260,1194,1051,868,814,768$, 750, 737, $615 \mathrm{~cm}^{-1}$; UV-vis (MeCN): $\lambda_{\max }(\varepsilon)=341 \mathrm{sh}(4300), 308 \mathrm{sh}(21600), 272 \mathrm{~nm}$ (35700 $\left.\mathrm{M}^{-1} \mathrm{~cm}^{-1}\right)$; HRMS: $\mathrm{m} / \mathrm{z}:$ 727.1951, calc. 727.1967 for $\left[\mathrm{M}^{+}-\mathrm{BF}_{4}\right]$.

\section{Synthesis of $\left[\operatorname{Ir}(\mathbf{p p z}-6)_{2}(\right.$ bipy $\left.)\right] B_{4}$}

Following the general procedure (GP3) with $\mathrm{IrCl}_{3} . \mathrm{xH}_{2} \mathrm{O}(117 \mathrm{mg}, 0.4 \mathrm{mmol})$ and ppz6 (234 mg, $0.8 \mathrm{mmol})$. [Ir(ppz-6)2(bipy)]BF 4 was isolated as a yellow solid (161 mg, 78 \%). ${ }^{1} \mathrm{H}$ NMR (400 MHz, [D6]acetone, $\left.25^{\circ} \mathrm{C}\right): \delta=8.78\left(\mathrm{~d},{ }^{3} \mathrm{~J}_{\mathrm{HH}}=8.1 \mathrm{~Hz}, 2 \mathrm{H}\right), 8.27-$ $8.20(\mathrm{~m}, 2 \mathrm{H}), 8.07\left(\mathrm{ddd},{ }^{3} \mathrm{~J}_{\mathrm{HH}}=5.5,1.5,0.7 \mathrm{~Hz}, 2 \mathrm{H}\right), 7.72\left(\mathrm{~d},{ }^{3} \mathrm{~J}_{\mathrm{HH}}=8.9 \mathrm{~Hz}, 2 \mathrm{H}\right), 7.61$ $\left(\mathrm{ddd},{ }^{3} \mathrm{~J}_{\mathrm{HH}}=7.6,5.5,1.2 \mathrm{~Hz}, 2 \mathrm{H}\right), 7.46\left(\mathrm{dd}, \mathrm{J}_{\mathrm{HH}}=9.0,2.6 \mathrm{~Hz}, 2 \mathrm{H}\right), 6.46\left(\mathrm{~d},{ }^{3} \mathrm{~J}_{\mathrm{HH}}=\right.$ $2.6 \mathrm{~Hz}, 2 \mathrm{H}), 6.32(\mathrm{~s}, 2 \mathrm{H}), 2.80(\mathrm{~s}, 6 \mathrm{H}), 1.51(\mathrm{~s}, 6 \mathrm{H}) \mathrm{ppm} ;{ }^{13} \mathrm{C}\left\{{ }^{1} \mathrm{H}\right\} \mathrm{NMR}(100 \mathrm{MHz}$, [D6]acetone, $25^{\circ} \mathrm{C}$ ): $\delta=157.5,152.9,151.8,147.6,144.9,141.2,140.2,134.3,130.2$, 129.7, 126.0, 122.6, 114.1, 112.2, 14.3, 12.3 ppm; IR (solid): $v$ bar = 2971, 1470, 1439, 1421, 1396, 1371, 1105, 1063, 1028, 839, 831, 787, 766, 725, 658, $592 \mathrm{~cm}^{-1}$; UV-vis $(\mathrm{MeCN}): \lambda_{\max }(\varepsilon)=340 \mathrm{sh}(6800), 310 \mathrm{sh}(18300), 297 \mathrm{sh}(24400), 272 \mathrm{~nm}\left(37100 \mathrm{M}^{-}\right.$ $\left.{ }^{1} \mathrm{~cm}^{-1}\right)$; HRMS: $\mathrm{m} / \mathrm{z}$ : 943.1251 , calc. 943.1280 for $\left[M^{+}-\mathrm{BF}_{4}\right]$.

\section{General Procedure 4 (GP4): Preparation of fluorinated pyrazole-Iridium complexes using microwave irradiation as exemplified by the synthesis of $\left[\operatorname{Ir}(p p z-1)_{2}(\right.$ bipy $\left.)\right] B F_{4}$}

$\mathrm{IrCl}_{3 .} \mathrm{xH}_{2} \mathrm{O}$ (180 mg, $\left.0.6 \mathrm{mmol}\right)$, ppz-1 (310 mg, $\left.1.2 \mathrm{mmol}\right), \mathrm{H}_{2} \mathrm{O}(2 \mathrm{~mL})$ and 2-methoxyethanol $(6 \mathrm{~mL})$ were heated in a microwave for $15 \mathrm{~min}$ at $180{ }^{\circ} \mathrm{C}$. The solution was cooled and $\mathrm{H}_{2} \mathrm{O}$ added $(\sim 20 \mathrm{~mL})$. The resulting grey precipitate was filtered and oven dried to give chloro-bridged dimer $\left[\operatorname{Ir}(\mathrm{ppz}-1)_{2}(\mu-\mathrm{Cl})_{2}(\mathrm{ppz}-1)_{2}\right]$. [Ir(ppz1) $\left.)_{2}(\mu-\mathrm{Cl})_{2}(\mathrm{ppz}-1)_{2}\right](270 \mathrm{mg}, 0.19 \mathrm{mmol})$ was split using MeCN $(5 \mathrm{~mL})$ and $\mathrm{AgBF}_{4}(74$ $\mathrm{mg}, 0.38 \mathrm{mmol}$ ) heating in the microwave at $120^{\circ} \mathrm{C}$ for $10 \mathrm{~min}$. The solution was cooled, filtered through cotton wool and the solvent removed in vacuo. The crude complex was precipitated from minimal dichloromethane and hexane as a grey oily solid, [Ir(ppz-1) $)_{2}(\mathrm{MeCN})_{2} \mathrm{BF}_{4}$. [Ir(ppz-1) $\left.)_{2}(\mathrm{MeCN})_{2}\right] \mathrm{BF}_{4}(260 \mathrm{mg}, 0.31 \mathrm{mmol})$ and 2,2'bipyridine $(49 \mathrm{mg}, 0.31 \mathrm{mmol})$ were dissolved in $\mathrm{CHCl}_{3}(7 \mathrm{~mL})$ and heated in the microwave at $130{ }^{\circ} \mathrm{C}$ for $15 \mathrm{~min}$. The solution was cooled and the solvent removed in vacuo. The crude solid was dissolved in minimal dichloromethane and added drop wise to stirring $\mathrm{Et}_{2} \mathrm{O}(15 \mathrm{~mL})$ at $0^{\circ} \mathrm{C}$. Further purification was achieved using column chromatography (silica) and eluting with 99:1 DCM/MeOH. The resultant precipitate was filtered to give [Ir(ppz-1)2(bipy)]BF4 as a yellow solid (110 mg, 40\%).

\section{Synthesis of $\left[\operatorname{Ir}(\mathbf{p p z}-2)_{2}\left({\text { bipy })] B F_{4}}_{4}\right.\right.$}

Following the general procedure (GP4) with $\left[\operatorname{Ir}(\mathrm{ppz}-2)_{2}\left(\mathrm{MeCN}_{2}\right] \mathrm{BF}_{4}(42 \mathrm{mg}, 0.050\right.$ $\mathrm{mmol})$. [Ir(ppz-2)2(bipy)]BF4 was isolated as a light yellow solid (26 mg, 57\%). 
Following the general procedure (GP3) with $\left[\operatorname{Ir}(\mathrm{ppz}-3)_{2}(\mathrm{MeCN})_{2}\right] \mathrm{BF}_{4}(318 \mathrm{mg}, 0.38$ $\mathrm{mmol}$ ). Further purification was achieved using column chromatography (silica) and eluting with 99:1 DCM/MeOH. [Ir(ppz-3) ${ }_{2}($ bipy) $] \mathrm{BF}_{4}$ was isolated as a green/yellow solid (26 mg, 22\%).

\section{Synthesis of $\left[\operatorname{Ir}(p p z-4)_{2}(\right.$ bipy $\left.)\right] B_{4}$}

Following the general procedure (GP3) with $\left[\operatorname{lr}(\mathrm{ppz}-4)_{2}(\mathrm{MeCN})_{2}\right] \mathrm{BF}_{4}(111 \mathrm{mg}, 0.116$ $\mathrm{mmol})$. [Ir(ppz-4)2(bipy)]BF4 was isolated as an off-white solid (167 mg, 76\%).

\section{Synthesis of $\left[\operatorname{Ir}(p p z-5)_{2}(\right.$ bipy $\left.)\right] B_{4}$}

Following the general procedure (GP3) with $\left[\operatorname{Ir}(\mathrm{ppz}-5)_{2}(\mathrm{MeCN})_{2}\right] \mathrm{BF}_{4}(50 \mathrm{mg}, 0.067$ $\mathrm{mmol})$. [Ir(ppz-5)2(bipy)]BF4 was isolated as a yellow solid (29 mg, 53\%).

\section{Synthesis of $\left[\operatorname{Ir}(p p z-6)_{2}(\right.$ bipy $\left.)\right] B_{F_{4}}$}

Following the general procedure (GP3) with $\left[\mathrm{Ir}(\mathrm{ppz}-6)_{2}(\mathrm{MeCN})_{2}\right] \mathrm{BF}_{4}(85 \mathrm{mg}, 0.089$ $\mathrm{mmol})$. $\left[\mathrm{Ir}(\mathrm{ppz}-6)_{2}(\mathrm{bipy})\right] \mathrm{BF} 4$ was isolated as a yellow solid (64 $\left.\mathrm{mg}, 71 \%\right)$.

\section{Acknowledgements}

We thank Cardiff University for generous support, including an Endowment Studentship (L.M.G.), and the Royal Society for a Research Grant (D.L.B., award number RG150376). ${ }^{\S}$ These authors contributed equally.

\section{Notes and references}

‡ CCDC1528005 and 1528006 contains supplementary X-ray crystallographic data for $\left[\operatorname{Ir}(\mathrm{ppz}-3)_{2}(\mathrm{bpy})\right] \mathrm{BF} 4$ and $\left[\operatorname{Ir}(\mathrm{ppz}-6)_{2}(\mathrm{bpy})\right] \mathrm{BF}_{4}$ respectively. This data can be obtained free of charge via http://www.ccdc.cam.ac.uk/conts/retrieving.html, or from the Cambridge Crystallographic Data Centre, Union Road, Cambridge, CB2 1EZ; fax(+44) 1223-336-033 or email: deposit@ccdc.cam.ac.uk. See DOI: $10.1039 / \times 0 \times x 00000 x$

\section{References}

[1] For some examples of papers describing the incorporation of machines in to synthetic chemistry see: 
a) A. McNally, C. K. Prier, D. W. C. MacMillan, Science 2011, 344, 1114; b) S. V. Ley, D. E. Fitzpatrick, R. M. Myers, C. Battilocchio, R. J. Ingham, Angew. Chem. Int. Ed. 2015, 54, 10122; c) R. J. Ingham, M. O'Brien, S. V. Ley, Beilstein J. Org. Chem. 2013, 9, 1051; d) L. Guetzoyan, R. J. Ingham, N. Nikbin, J. Rossignol, M. Wolling, M. Baumert, N. A. Burgess-Brown, C. M. StrainDamerell, L. Shrestha, P. E. Brennan, O. Fedorov, S. Knapp, S. V. Ley, MedChemComm 2014, 5, 540; e) A. Adamo, R. L. Beingessner, M. Behnam, J. Chen, T. F. Jamison, K. F. Jensen, J.-C. M. Monbaliu, A. S. Myerson, E. M. Revalor, D. R. Snead, T. Stelzer, N. Weeranoppanant, S. Y. Wong, P. Zhang, Science 2016, 352, 61; f) P. L. Heider, S. C. Born, S. Basak, B. Benyahia, R. Lakerveld, H. Zhang, R. Hogan, L. Buchbinder, A. Wolfe, S. Mascia, J. Evans, T. F. Jamison, K. F. Jensen, Org. Process React. Dev. 2014, 18, 402; g) S. Mascia, P. L. Heider, H. Zhang, R. Lakerveld, B. Benyahia, P. I. Barton, R. D. Braatz, C. L. Cooney, J. M. B. Evans, T. F. Jamison, K. F. Jensen, A. S. Meyerson, B. L. Trout, Angew. Chem. Int. Ed. 2013, 52, 12359.

[2] For examples of papers reporting inline analytics see: a) S. Schwolow, F. Braun, M. Rädle, N. Kockmann, T. Röder, Org. Process Res. Dev. 2015, 19, 1286; b) K. L. A. Chan, S. Gulati, J. B. Edel, A. J. de Mello, S. G. Kazarian, Lab Chip 2009, 9, 2909; c) C. F. Carter, H. Lange, S. V. Ley, I. R. Baxendale, B. Wittkamp, J. G. Goode, N. L. Gaunt, Org. Process Res. Dev. 2010, 14, 393; d) S. Newton, C. F. Carter, C. M. Pearson, L. D. Alves, H. Lange, P. Thansandote, S. V. Ley, Angew. Chem., Int. Ed. 2014, 53, 4915; e) D. L. Browne, S. Wright, B. J. Deadman, S. Dunnage, I. R. Baxendale, R. M. Turner, S. V. Ley, Rapid Commun. Mass Spectrom. 2012, 26, 1999; f) J. S. Mathieson, M. H. Rosnes, V. Sans, P. J. Kitson, L. Cronin, Beilstein J. Nanotechnol. 2013, 4, 285; g) J. Bart, A. J. Kolkman, A. J. Oosthoek-de Vries, K. Koch, P. J. Nieuwland, H. Janssen, J. van Bentum, K. A. M. Ampt, F. P. J. T. Rutjes, S. S. Wijmenga, H. Gardeniers, A. P. M. Kentgens, J. Am. Chem. Soc. 2009, 131, 5014; h) M. V. Gomez, H. H. J. Verputten, A. Diaz-Ortiz, A. Moreno, A. de la Hoz, A. H. Velders, Chem. Commun. 2010, 46, 4514.

[3] For examples of papers reporting/discussing self-optimization and the use of intelligent algorithms see: a) V. Sans, L. Cronin, Chem. Soc. Rev. 2016, 45, 2032; b) D. C. Fabry, E. Suiono, M. Rueping, React. Chem. Eng. 2016, 1, 129; c) J. Parrott, R. A. Bourne, G. R. Akien, D. J. Irvine, M. Poliakoff, Angew. 
Chem., Int. Ed. 2011, 50, 3788; d) R. A. Skilton, R. A. Bourne, Z. Amara, R. Horvath, J. Jin, M. J. Scully, E. Streng, S. L. Y. Tang, P. A. Summers, J. Wang, E. Pérez, N. Asfaw, G. L. P. Aydos, J. Dupont, G. Comak, M. W. George, M. Poliakoff, Nat. Chem. 2015, 7, 1; e) N. Holmes, G. R. Akien, R. J. D. Savage, C. Stanetty, I. R. Baxendale, A. J. Blacker, B. A. Taylor, R. L. Woodward, R. E. Meadows, R. A. Bourne, React. Chem. Eng. 2016, 1, 96; f) A. J. Parrott, R. A. Bourne, M. Poliakoff, J. Flow Chem. 2012, 2, 24; g) N. Holmes, G. R. Akien, A. J. Blacker, R. L. Woodward, R. E. Meadows, R. A. Bourne, React. Chem. Eng. 2016, 1, 366; h) J. P. McMullen, M. T. Stone, S. L. Buchwald, K. F. Jensen, Angew. Chem., Int. Ed. 2010, 49, 7076; i) H. Lange, C. F. Carter, M. D. Hopkin, A. Burke, J. G. Goode, I. R. Baxendale, S. V. Ley, Chem. Sci. 2011, 2, 765; j) J. S. Moore and K. F. Jensen, Org. Process Res. Dev., 2012, 16, 1409; k) D. C. Fabry, E. Sugiono, M. Rueping, Isr. J. Chem. 2014, 54, 341; I) S. Krishnadasan, R. J. C. Brown, A. J. deMello, J. C. deMello, Lab Chip 2007, 7, 1434.

[4] For papers reporting synthesis and biological screening machine platforms, see ref. 3d and: a) C. Battilocchio, L. Guetzoyan, C. Cervetto, L. D. C. Mannelli, D. Frattaroli, I. R. Baxendale, G. Maura, A. Rossi, L. Sautebin, M. Biava, C. Ghelardini, M. Marcoli, S. V. Ley, ACS Med. Chem. Lett. 2013, 4, 704; b) L. Guetzoyan, N. Nikbin, I. R. Baxendale, S. V. Ley, Chem. Sci. 2013, 4, 764; c) W. Czechtizky, J. Dedio, B. Desai, K. Dixon, E. Farrant, Q. Feng, T. Morgan, D. M. Parry, M. K. Ramjee, C. N. Selway, T. Schmidt, G. J. Tarver, A. G. Wright, ACS Med. Chem. Lett. 2013, 4, 768.

[5] For examples of the formation of metal-ligand complexes (of iridium) under continuous flow or microwave conditions, see ref 17 and: a) J. G. Krabbe, A. R. Boer, G. Van der Zwan, H. Lingerman, W. M. A. Niessen, H. Irth, J. Am. Chem. Soc. Mass Spectrom. 2007, 18, 707; b) H. Konno, Y. Sasaki, Chem. Lett. 2003, 32, 252; c) B. Beyer, C. Ulbricht, A. Winter, M. D. Hager, R. Hoogenboom, N. Herzer, S. O. Baumann, G. Kickelbick, H. Görls, U. S. Schubert, New J. Chem. 2010, 34, 2622.

[6] a) S. Ladouceur, E. Zysman-Colman, Eur. J. Inorg. Chem. 2013, 2985; b) A. Ruggi, F.W.B. van Leeuwen, A.H. Velders, Coord. Chem. Rev. 2011, 255, 2542; c) K. K-W. Lo, M-W. Louie, K.Y. Zhang, Coord. Chem. Rev. 2010, 254, 2603. 
[7] For example: a) S. Lamansky, P. Djurovich, D. Murphy, F. Abdel-Razzaq, H-E. Lee, C. Adachi, P.E. Burrows, S.R. Forrest, M.E. Thompson, J. Am. Chem. Soc. 2001, 123, 4304; b) A. Tsuboyama, H. Iwawaki, M. Furugori, T. Mukaide, J. Kamatani, S. Igawa, T. Moriyama, S. Miura, T. Takiguchi, S. Okada, M. Hoshino, K. Ueno, J. Am. Chem. Soc. 2003, 125, 12971; c) W-Y. Wong, G-J. Zhou, X-M. Yu, H-S. Kwok, B-Z. Tang, Adv. Funct. Mater. 2006, 16, 838.

[8] For example: a) J.I. Goldsmith, W.R. Hudson, M.S. Lowry, T.H. Anderson, S. Bernhard, J. Am. Chem. Soc. 2005, 127, 7502; b) S-Y. Takizawa, R. Aboshi, S. Murata, Photochem. Photobiol. Sci. 2011, 10, 895; c) A. J. Hallett, N. White, W. Wu, X. Cui, P. N. Horton, S. J. Coles, J. Zhao, S. J. A. Pope, Chem. Commun. 2012, 48, 10838

[9] For example: a) T. S-M. Tang, K-K. Leung, M-W. Louie, H-W. Liu, S.H. Cheng, K.K-W. Lo, Dalton Trans. 2015, 44, 4945; b) C. Li, M. Yu, Y. Sun, Y. Wu, C. Huang, F. Li, J. Am. Chem. Soc. 2011, 133, 11231; c) A. Juna, E. Baggaley, A.J. Amoroso, M.D. Ward, Chem. Commun. 2015, 51, 8833.

[10] G-G. Shan, H-B. Li, H-T. Cao, D-X. Zhu, P. Li, Z-M. Su, Y. Liao, Chem. Commun. 2012, 48, 2000.

[11] H. Sun, S. Liu, W. Lin, K.Y. Zhang, W. Lv, X. Huang, F. Huo, H. Yang, G. Jenkins, Q. Zhao, W. Huang, Nat. Commun. 2014, 5, 3601.

[12] a)T-H. Kwon, H.S. Cho, M.K. Kim, J-W. Kim, J-J. Kim, K.H. Lee, S.J. Park, I-S. Shin, H. Kim, D.M. Shin, Y.K. Chung, J-I. Hong, Organometallics 2005, 24, 1578; b) K. Hanson, L. Roskop, P. I. Djurovich, F. Zahariev, M. S. Gordon, M.E. Thompson, J. Am. Chem. Soc. 2010, 132, 16247; c) D. Sykes, I. S. Tidmarsh, A. Barbieri, I. V. Sazanovich, J. A. Weinstein, M. D. Ward, Inorg. Chem. 2011, 50, 11323; d) K. Hasan, A.K. Bansal, I.D.W. Samuel, C. RoldanCarmona, H.J. Bolink, E. Zysman-Colman, Scientific Rep. 2015, 5, 12325; f) E.E. Langdon-Jones, A.J. Hallett, J.D. Routledge, D.A. Crole, B.D. Ward, J.A. Platts, S.J.A. Pope, Inorg. Chem. 2013, 52, 448; g) P. Brulatti, R.J. Gildea, J.A.K. Howard, V. Fattori, M. Cocchi, J.A.G. Williams, Inorg. Chem. 2012, 51, 3813 ;

[13] A.F. Henwood, E. Zysman-Colman, Chem. Commun. 2017, 53, 807.

[14] For a continuous flow process using ascorbic acid, see: a) J. S. Poh, D. L. Browne, S. V. Ley, React. Chem. Eng. 2016, 1, 101; b) D. L. Browne, I. R. Baxendale, S. V. Ley, Tetrahedron, 2011, 67, 10296. For examples of 
processes using tin(II) chloride or sodium sulfite as reducing agent for diazonium salts, see: c) B. Li, D. Widlicka, S. Boucher, C. Hayward, J. Lucas, J. C. Murray, B. T. O'Neil, D. Pfisterer, L. Samp, J. VanAlsten, Y. Xiang, J. Young, Org. Process Res. Dev. 2012, 16, 2031; d) G. H. Coleman, Org. Synth. 1922, 2, 71; e) J. P. Koilpillai, M. Subramanian, U. Mallela, V. B. Boddu, R. Dandala, S. Meenakshisunderam, Aurobindo Pharma Ltd., Patent WO 2008/075163, 26 June 2008; f) Z. Yu, G. Tong, X. Xie, P. Zhou, Y. Lv, W. Su, Org. Process Res. Dev. 2015, 19, 892.

[15] M. Nonoyama, Bull. Chem. Soc. Jpn. 1974, 47, 767.

[16] a) P. Alam, I.R. Laskar, C. Climent, D. Casanova, P. Alemany, M. Karanam, A.R. Choudhury, J.R. Butcher, Polyhedron 2013, 53, 286; b) Q-H. Wu, C-H. Wang, X-m. Song, G-L. Zhang, Chin. J. Chem. Phys. 2010, 23, 355; b) K. Saito, N. Matsusue, H. Kanno, Y. Hamada, H. Takahashi, T. Matsumura, Jpn. J. Appl. Phys. 2004, 43, 2733; c) H. Konno, Chem. Lett. 2003, 32, 252; d) E.C. Constable, C.E. Housecroft, E. Schönhofer, J. Schönle, J.A. Zampese, Polyhedron 2012, 35, 154.

[17] T.M. Monos, A.C. Sun, R.C. McAtee, J.J. Devery, III, C.R.J. Stephenson, J. Org. Chem. 2016, 81, 6988.

[18] D.L. Davies, M.P. Lowe, K.S. Ryder, K. Singh, S. Singh, Dalton Trans. 2011, 40, 1028.

[19] R.D. Costa, E. Orti, D. Tordera, A. Pertegas, H.J. Bolink, S. Graber, C.E. Housecroft, L. Sachno, M. Neuburger, E.C. Constable, Adv. Energy Mater. 2011, 1, 282.

[20] A.B. Tamayo, S. Garon, T. Sajoto, P.I. Djurovich, I.M. Tsyba, R. Bau, M.E. Thompson, Inorg. Chem. 2005, 44, 8723.

[21] N.M. Shavaleev, G. Xie, S. Varghese, D.B. Cordes, A.M.Z. Slawin, C. Momblona, E. Orti, H.J. Bolink, I.D.W. Samuel, E. Zysman-Colman, Inorg. Chem. 2015, 54, 5907

[22] L. Flamigni, B. Ventura, F. Barigelletti, E. Baranoff, J-P. Collin, J-P. Sauvage, Eur. J. Inorg. Chem. 2005, 1312.

[23] A. Juris, V. Balzani, F. Barigelletti, S. Campagna, P. Belser, A. von Zelewsky, Coord. Chem. Rev. 1988, 84, 85.

[24] S.J. Coles, P.A. Gale, Chem. Sci. 2012, 3, 683. 
[25] Rigaku, CrystalClear- SM Expert 3.1 b27, 2013

[26] CrysAlisPro Software System, Rigaku Oxford Diffraction, Yarnton, Oxford, UK (2015).

[27] O.V. Dolomanov, L.J. Bourhis, R.J. Gildea, J.A.K. Howard, H. Puschmann, J. Appl. Cryst. 2009, 42, 339.

[28] G.M. Sheldrick, Acta Cryst. 2015, A71, 3.

[29] G.M. Sheldrick, Acta Cryst. 2015, C27, 3.

[30] a) A. D. Becke, J. Chem. Phys. 1993, 98, 5648; b) C. Lee, W. Yang, and R. G. Parr, Phys. Rev. B 1988, 37, 785.

[31] a) M. M. Francl, W. J. Pietro, W. J. Hehre, J. S. Binkley, D. J. DeFrees, J. A.

Pople and M. S. Gordon, J. Chem. Phys. 1982, 77, 3654. b) P. C. Hariharan and J.

A. Pople, Theor. Chem. Acc. 1973, 28, 213.

[32] D. Andrae, U. Haeussermann, M. Dolg, H. Stoll, H. Preuss, Theor. Chem. Acc.

1990, 77, 123.

[33] T. Clark, J. Chandrasekhar, G. W. Spitznagel, P. v. R. Schleyer, J. Comp.

Chem. 1983, 4, 294.

[34] T. Yanai, D. Tew, and N. Handy, Chem. Phys. Lett. 2004, 393, 51.

[35] Robb, J. R. Cheeseman, J. A. Montgomery Jr., T. Vreven, K. N. Kudin, J. C.

Burant, J. M. Millam, S. S. Iyengar, J. Tomasi, V. Barone, B. Mennucci, M. Cossi, G.

Scalmani, N. Rega, G. A. Petersson, H. Nakatsuji, M. Hada, M. Ehara, K. Toyota, R.

Fukuda, J. Hasegawa, M. Ishida, T. Nakajima, Y. Honda, O. Kitao, H. Nakai, M.

Klene, X. Li, J. E. Knox, H. P. Hratchian, J. B. Cross, V. Bakken, C. Adamo, J.

Jaramillo, R. Gomperts, R. E. Stratmann, O. Yazyev, A. J. Austin, R. Cammi, C.

Pomelli, J. W. Ochterski, P. Y. Ayala, K. Morokuma, G. A. Voth, P. Salvador, J. J.

Dannenberg, V. G. Zakrzewski, S. Dapprich, A. D. Daniels, M. C. Strain, O. Farkas,

D. K. Malick, A. D. Rabuck, K. Raghavachari, J. B. Foresman, J. V. Ortiz, Q. Cui, A.

G. Baboul, S. Clifford, J. Cioslowski, B. B. Stefanov, G. Liu, A. Liashenko, P. Piskorz, I. Komaromi, R. L. Martin, D. J. Fox, T. Keith, M. A. Al-Laham, C. Y. Peng, A.

Nanayakkara, M. Challacombe, P. M. W. Gill, B. Johnson, W. Chen, M. W. Wong, C. Gonzalez, J. A. Pople, Gaussian 03, Revision E.01. Gaussian, Inc., Wallingford CT, 2004.

[36] N.G. Connelly, W.E. Geiger, Chem. Rev. 1996, 96, 877. 


\section{Schemes and Figures Legends}

Figure 1. This work: proof of concept, chemistry model validation and development of synthesis machines 1 and 2 .

Scheme 1. Preparation of fluorinated pyrazole ligands using a continuous flow-microwave hybrid approach.

Scheme 2. Summary of the synthetic routes to the ligands and complexes.

Scheme 3. Structures and comparison of preparative yields of the substituted phenylpyrazole ligands.

Scheme 4. Structures, total reaction times and comparative yields (final step) of the isolated Ir III-pyrazolato complexes.

Figure 2. Molecular structures of the iridium complexes (top: [Ir(ppz-3) $)_{2}($ bipy)]BF 4 ; bottom: $\left[\operatorname{Ir}(\mathrm{ppz}-6)_{2}\left(\mathrm{bipy}_{\mathrm{i}}\right] \mathrm{BF}_{4}\right)$. Thermal ellipsoids drawn at the $30 \%$ probability level. Hydrogen atoms, anions and solvent molecules are omitted for clarity.

Figure 3: Isosurface plots for HOMO (left) and LUMO (right) of $\left[\operatorname{Ir}(\mathrm{ppz}-5)_{2}(\text { bipy })\right]^{+}$, displayed at 0.04 au.

Figure 4. Comparison of the UV-vis. spectra for the complexes (in MeCN).

Figure 5. Main: Normalised emission spectra of the complexes $\left(\mathrm{MeCN}, \lambda_{\mathrm{ex}}=380 \mathrm{~nm}\right)$. Foreground: emission spectra at $77 \mathrm{~K}\left(\mathrm{MeOH} / \mathrm{EtOH}\right.$ glass, $\left.\lambda_{\mathrm{ex}}=380 \mathrm{~nm}\right)$.

Figure 6. Transient absorption spectra and data. Left: a 3D time-resolved plot for [Ir(ppz$3)_{2}$ (bipy)]BF 4 . Right: fitted (red trace) lifetime profiles for the different Ir III complexes. The lowest panel shows, as an exemplar, the recovery of the spectral feature assigned as a bleach at $\lambda=310 \mathrm{~nm}$ for $\left[\operatorname{Ir}(\mathrm{ppz}-3)_{2}(\right.$ bipy $\left.)\right] \mathrm{BF}_{4}$. The recovery of the bleach occurs on a timescale similar to the decay of the absorption features at longer wavelengths.

Table 1. Calculated HOMO and LUMO energies and \% $5 d$ orbital character of the HOMO for each complex.

Table 2 Photophysical properties of the $\left[\operatorname{Ir}(\mathrm{ppz})_{2}(\right.$ bipy $\left.)\right] \mathrm{BF}_{4}$ complexes. $\left.a\right)$ recorded at RT in aerated $\mathrm{MeCN}\left(\lambda_{\mathrm{ex}}=405 \mathrm{~nm}\right) ;{ }^{b}$ values in parentheses were obtained at $77 \mathrm{~K}(1: 1$ $\mathrm{MeOH} / \mathrm{EtOH}$ glass); ${ }^{c}$ values in parentheses are the lifetimes obtained from time-resolved transient absorption measurements.

Table 3. Electrochemical properties of the $\left[\operatorname{Ir}(\mathrm{ppz})_{2}(\mathrm{bipy}) \mathrm{BF}_{4}\right.$ complex. $a$ ) oxidation potentials were measured as dichloromethane solutions at $200 \mathrm{mVs}^{-1}$ with $0.1 \mathrm{M}$ $\left[\mathrm{NBu}_{4}\right]\left[\mathrm{PF}_{6}\right]$ as supporting electrolyte calibrated with $\mathrm{Fc} / \mathrm{Fc}^{+}$at $+0.46 \mathrm{~V}$; ${ }^{\mathrm{b}}$ irreversible wave; ${ }^{\mathrm{c}}$ reversible wave; ${ }^{d}$ the $\mathrm{HOMO}$ energy level was calculated using the equation $-E_{\text {HOMO }}(\mathrm{eV})=$ $E_{\mathrm{Ox}}-\mathrm{E}_{\mathrm{Fc} / \mathrm{Fc}+}+4.8$; ${ }^{\mathrm{e}} E_{\text {bandgap }}$ was determined from the absorption edge of the iridium 
complexes; $^{f}$ the LUMO energy level was calculated using the equation $E_{\mathrm{LUMO}}(\mathrm{eV})=E_{\mathrm{HOMO}}+$ Ebandgap

Table 1 Calculated HOMO and LUMO energies and \% $5 d$ orbital character of the HOMO for each complex.

\begin{tabular}{|c|c|c|c|c|c|}
\hline Complex & & Eномо / eV & ELUMo / eV & $E_{\text {Bandgap }} / \mathrm{eV}$ & $\% 5 d(\mathrm{HOMO})$ \\
\hline 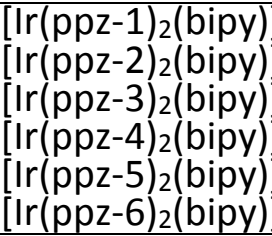 & $\begin{array}{l}\mathrm{BF}_{4} \\
\mathrm{BF}_{4} \\
\mathrm{BF}_{4} \\
\mathrm{BF}_{4} \\
\mathrm{BF}_{4} \\
\mathrm{BF}_{4}\end{array}$ & $\begin{array}{l}-8.31 \\
-8.46 \\
-8.40 \\
-8.68 \\
-8.15 \\
-8.61 \\
\end{array}$ & $\begin{array}{l}-5.39 \\
-5.47 \\
-5.42 \\
-5.59 \\
-5.33 \\
-5.54\end{array}$ & $\begin{array}{l}2.92 \\
2.99 \\
2.98 \\
3.09 \\
2.82 \\
3.07 \\
\end{array}$ & $\begin{array}{l}17.3 \\
12.5 \\
14.7 \\
21.9 \\
13.5 \\
21.8 \\
\end{array}$ \\
\hline
\end{tabular}

Table 2 Photophysical properties of the $\left[\operatorname{Ir}(\mathrm{ppz})_{2}(\mathrm{bipy})\right] \mathrm{BF}_{4}$ complexes.

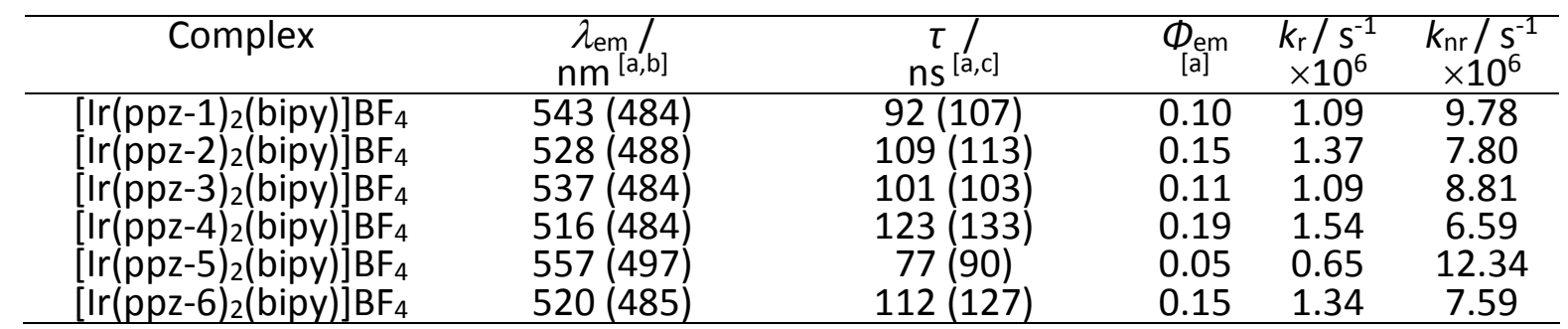

${ }^{a}$ recorded at RT in aerated MeCN $\left(\lambda_{\mathrm{ex}}=405 \mathrm{~nm}\right) ;{ }^{b}$ values in parentheses were obtained at $77 \mathrm{~K}\left(1: 1 \mathrm{MeOH} / \mathrm{EtOH}\right.$ glass); ${ }^{c}$ values in parentheses are the lifetimes obtained from timeresolved transient absorption measurements.

Table 3 Electrochemical properties of the $\left[\operatorname{lr}(\mathrm{ppz})_{2}(\mathrm{bipy})\right] \mathrm{BF}_{4}$ complex.

\begin{tabular}{|c|c|c|c|c|c|}
\hline Complex & $E_{\mathrm{ox}} / \mathrm{V}^{[\mathrm{a}]}$ & $E_{\text {red }} / \mathrm{V}^{[\mathrm{a}]}$ & $\underset{[\mathrm{d}]}{\mathrm{HOMO}} / \mathrm{eV}$ & LUMO / eV ${ }^{[\mathrm{f}]}$ & $\begin{array}{c}E_{\text {bandgap }} / \\
\left.\mathrm{eV}^{\mathrm{e}}\right]\end{array}$ \\
\hline$\left[\operatorname{Ir}(p p z-1)_{2}(\right.$ bipy) $] \mathrm{BF}_{4}$ & $+1.62^{[\mathrm{b}]}$ & $-1.33^{[b]}$ & -5.96 & -3.43 & 2.53 \\
\hline$\left[\operatorname{Ir}(\mathrm{ppz}-2)_{2}(\mathrm{bipy})\right] \mathrm{BF}_{4}$ & $+1.66^{[b]}$ & $-1.32^{[c]}$ & -6.00 & -3.44 & 2.56 \\
\hline$\left[\operatorname{Ir}(\mathrm{ppz}-3)_{2}(\mathrm{bipy})\right] \mathrm{BF}_{4}$ & $+1.60^{[c]}$ & $-1.35^{[c]}$ & -5.94 & -3.39 & 2.55 \\
\hline$\left[\operatorname{lr}(\mathrm{ppz}-4)_{2}(\mathrm{bipy})\right] \mathrm{BF}_{4}$ & $+1.74^{[\mathrm{b}]}$ & $-1.30^{[c]}$ & -6.08 & -3.52 & 2.56 \\
\hline$\left[\operatorname{lr}(\mathrm{ppz}-5)_{2}(\mathrm{bipy})\right] \mathrm{BF}_{4}$ & $+1.47^{[c]}$ & $-1.47^{[b]}$ & -5.81 & -3.30 & 2.51 \\
\hline$\left[\operatorname{lr}(\mathrm{ppz}-6)_{2}(\mathrm{bipy})\right] \mathrm{BF}_{4}$ & $+1.75^{[\mathrm{b}\rfloor}$ & $-1.30^{\lfloor b]}$ & -6.09 & -3.47 & 2.62 \\
\hline
\end{tabular}

${ }^{a}$ oxidation potentials were measured as dichloromethane solutions at $200 \mathrm{mVs}^{-1}$ with $0.1 \mathrm{M}$ $\left[\mathrm{NBu}_{4}\right]\left[\mathrm{PF}_{6}\right]$ as supporting electrolyte calibrated with $\mathrm{Fc} / \mathrm{Fc}^{+}$at $+0.46 \mathrm{~V} ;{ }^{b}$ irreversible wave; ${ }^{\mathrm{c}}$ reversible wave; ${ }^{d}$ the HOMO energy level was calculated using the equation $-E_{\text {Hомо }}(\mathrm{eV})=$ $E_{\mathrm{ox}}-\mathrm{E}_{\mathrm{Fc} / \mathrm{Fc}+}+4.8 ;{ }^{\mathrm{e}} E_{\text {bandgap }}$ was determined from the absorption edge of the iridium complexes; ${ }^{f}$ the LUMO energy level was calculated using the equation $E_{\mathrm{LUMO}}(\mathrm{eV})=E_{\mathrm{HOMO}}+$ Ebandgap 
Synthesis machines can rapidly produce novel iridium-based phosphors with tuneable luminescence and redox properties. 